\title{
Role of Collectins and Complement Protein C1q in pregnancy and parturition
}

Shanmuga Priyaa Madhukaran ${ }^{1,2}$, Fatimah S. Alhamlan ${ }^{3}$, Kavita Kale ${ }^{4}$, Manu Vatish ${ }^{5}$, Taruna Madan $^{4}$, Uday Kishore ${ }^{*}$

${ }^{1}$ Biosciences, College of Health and Life Sciences, Brunel University London, Uxbridge UB8 3PH, United Kingdom

${ }^{2}$ Centre for Biotechnology and Bioinformatics, School of Life Sciences, Jawaharlal Nehru Institute for Advanced Studies, Secunderabad, Telangana, India

${ }^{3}$ Department of Infection and Immunity, King Faisal Specialist Hospital and Research Centre, Riyadh, Saudi Arabia

${ }^{4}$ Department of Innate Immunity, National Institute for Research in Reproductive Health, Mumbai 400 012, India

${ }^{5}$ Nuffield Department of Obstetrics \& Gynaecology, University of Oxford, Oxford, OX3 9DU, UK

*Author for correspondence: Dr. Uday Kishore (Uday.Kishore@brunel.ac.uk; ukishore@hotmail.com)

Running Title: Soluble defense collagens in pregnancy and parturition 


\section{ABSTRACT}

Collectins such as surfactant proteins SP-A, SP-D, and mannan-binding lectin (MBL), as well as complement protein $\mathrm{C} 1 \mathrm{q}$ are evolutionarily conserved innate immune molecules. They are known to opsonize a range of microbial pathogens (bacteria, fungi, virus, and parasites) and trigger effector clearance mechanisms involving phagocytosis and/or complement activation. Collectins and C1q have also attracted attention in studies involving pregnancy as they are expressed in the female reproductive tissues during pregnancy; a unique state of immune suppression with increased susceptibility to infectious diseases. Recent studies are beginning to unravel their functional significance in implantation, placentation, pregnancy maintenance and parturition in normal and adverse pregnancies. Collectins and C1q, expressed in gestational tissues during pregnancy, might alter the status of mother's immune response to the allogenic fetus and the microenvironment, thereby serving as important regulators of fetus-mother interaction. Here, we discuss the functional roles that have been assigned to SPA, SP-D, MBL and C1q in pregnancy and parturition.

Keywords: surfactant proteins; complement; pregnancy; parturition; preeclampsia 


\section{Introduction}

The innate immune system is activated by receptors that recognize pathogen-associated molecular patterns (PAMPs) and bring about inflammatory responses, thus acting as immunomodulators (Janeway and Medzhitov, 2002). These receptors have the ability to distinguish self from non-self molecules by recognizing the specific orientation of hydroxyl groups of hexoses (mannose, glucose, fructose and N-acetyl-D-glucosamine) and charge patterns, which are present on the surface of microbes (Medzhitov, 2007). This binding promotes clearance of pathogens via neutralisation, agglutination, and/or phagocytosis (Kawai and Akira, 2010).

Collectins belong to a family of evolutionarily conserved mammalian pattern recognition molecules that are characterized by calcium-dependent (C-type lectin) carbohydrate binding domain (Epstein et al., 1996). Its members include surfactant protein A and D (SP-A and SP-D), mannose binding lectin (MBL), scavenger receptor collectin placenta-1 (CL-P1), collectin liver-1 (CL-L1), collectin kidney-1 (CL-K1), conglutinin, collectin of $43 \mathrm{kDa}$ (CL-43), and collectin of $46 \mathrm{kDa}$ (CL-46) (Kishore et al., 2006).

SP-A, SP-D and MBL are soluble oligomeric proteins. The structural organization of SP-A, SP-D and MBL includes four distinct regions: a short cysteine containing N-terminal region with disulphide bonds, a proline rich triple-helical collagen region with Gly-X-Y repeats, a hydrophobic $\alpha$-helical coiled coil neck region, and a C-terminal lectin /carbohydrate recognition domain (CRD) region (Kishore et al., 2006). The collagen domain is known to have receptors on various immune cells including calreticulin-CD91 receptor complex (Gardai et al, 2003). Humans contain two highly similar SP-A genes, SPA-1 (SFTPA-1) with 5 exons and SP-A2 (SFTPA-2) with 6 exons (Katyal et al., 1992; McCormick et al., 1994). SP-A is composed of $650 \mathrm{kDa}$, hexameric structure of six trimers. Its collagen domain with 23 Gly-X-Y repeats is interrupted by a kink giving rise to a structure resembling a bouquet of tulips (Voss et al., 1988). SP-D appears as a cruciform structure due to its tetrameric structure $(520 \mathrm{kDa})$ with 4 trimers (Figure 1) (Crouch et al., 1994).

MBL is composed of six $96 \mathrm{kDa}$ trimeric subunits and with bouquet-like structure similar to SP-A due to kink interruption within 19 Gly-X-Y repeats. Unlike other collectins, MBL can activate the lectin pathway of the complement cascade via MBL associated serine proteases (MASPs) (Ji et al., 1997; Thiel et al., 1997; Thiel, 2007; Degn et al., 2012). MBL2 gene encoding functional human MBL protein has 3 single nucleotide polymorphisms (SNPs) 
at codon 52 (variant D-alelle, Arg52 Cys), codon 54 (Variant B-allele, Gly54 Asp) and codon 57 (Variant C allele, Gly57 Glu). SNPs within the MBL2 at codon 54 consist of two variants: allele A (wild type) and allele B (Madsen et al, 1994; Madsen et al, 1995). SP-A, SP-D and MBL have been extensively shown to involved in innate immune anti-microbial defence via a range of mechanisms including modulation of adaptive immunity, and thus, feature centrally in the regulation of inflammation.

Complement component $\mathrm{Clq}(460 \mathrm{kDa})$ is the first subcomponent of the complement classical pathway with three polypeptide chains (A, B and C). The A, B and C chains comprise of $\mathrm{N}$ terminal domain with cysteine residues, a collagen-like region (CLR), and a C-terminal globular domain (gC1q) (Sellar et al., 1992). C1q is involved in innate host defence and several modulatory process including pathogen clearance, apoptosis, angiogenesis, chemotaxis, cell differentiation, adhesion, migration, coagulation via platelets, autoimmunity, isotype switching, tolerance (Kishore et al., 2004).

The human genes for SP-A, SP-D and MBL are located on the long arm of chromosome 10 between 10q21-24 (Crouch et al., 1993). All three A, B and C chains of human C1q are located on chromosome 1p34.1-1p36.3 (Sellar et al., 1992) (Table 1). The ciliated alveolar epithelial type II pneumocytes and non-ciliated bronchial Clara cells in lungs are the major source of SP-A and SP-D (Ballard et al., 1986; Persson et al., 1988). Unlike most of the collectins largely synthesized by lungs, MBL and C1q are synthesized in the liver (Kawasaki et al., 1978). However, extra-pulmonary and extra-hepatic biosynthesis of collagens have been reported (Table 2). Using RT-PCR, expression of SP-A, SP-D, MBL and C1q transcripts have also been shown in salivary glands, lacrymal glands (Madsen et al., 2003), pancreas, bile ducts, thymus, prostate (Madsen et al., 2000), colon (Eliakim et al., 1997), small and large intestine (Uemura et al., 2002), brain, spleen (Wagner et al., 2003), Kidney (Ezekowitz et al., 1988), epithelial cells, mesenchymal cells (Morris et al., 1978), dendritic cells (Vegh et al., 2003), microglial cells (Farber et al., 2009) (Table 2).

The roles of collectins and $\mathrm{C} 1 \mathrm{q}$ are not solely restricted to recognition and elimination of pathogens. Evidence clearly demonstrates that these soluble defence collagens are at the crossroads of both innate and adaptive immunity as they regulate inflammation, hostpathogen interaction, immune tolerance and offer immune protection at multiple levels. Furthermore, their deficiency and dysregulated expression has been associated with infectious diseases. An intriguing feature of collectins (SP-A, SP-D, and MBL) is that they exhibit dual immunological function (pro-inflammatory and anti-inflammatory) based on their interaction with candidate receptors, SIRP- $\alpha$ and calreticulin/CD91 (Gardai et al., 
2003). Recent studies have highlighted the importance of these soluble proteins in novel functions related to maintenance of pregnancy (implantation, vascular remodeling, and placental formation) and parturition. Here, we discuss collectins and C1q with respect to their cellular sources, their expression in the female reproductive system, and their roles in pregnancy and parturition.

\section{Expression of collectins and C1q in the female reproductive system}

\section{Peripheral blood and serum}

During pregnancy, no significant changes can be observed in the levels of SP-A in maternal serum before $(7-74 \mathrm{ng} / \mathrm{ml})$ or after labor $(9.6-73.6 \mathrm{ng} / \mathrm{ml})$ (Cho et al., 1999). The concentration of serum MBL in various individuals varies depending on the SNPs in the promoter region and the coding region (exon-1) of the MBL-2 gene (Bodamer et al., 2006). The structural mutation in exon-1 (encoding a single polypeptide region, a cysteine rich region and a part of collagen region) of the MBL-2 gene has been proposed to impair higher oligomer formation preventing the functional ability of MBL to activate the complement lectin pathway via MASPs (Matsushita et al., 1995; Terai et al., 2003; Roos et al., 2003). It may be concluded that polymorphisms in the promoter region significantly decrease the serum MBL level, and hence, very little amount of higher oligomeric forms of MBL can be observed in serum when compared to trimeric and tetrameric forms. During pregnancy, MBL genotypes and polymorphisms correlate with the serum concentration of MBL. Hence, serum levels of MBL increase in the first trimester and then decrease in the $6^{\text {th }}$ week post-partum (van de Geijn et al., 2007a). In another study, levels of MBL in the peripheral blood remain relatively constant throughout pregnancy in all three trimesters and at delivery, but decreases sharply after delivery (Thevenon et al., 2009).

C1q levels in normal pregnancies were significantly lower than in non-pregnant women, and levels in spontaneous abortions were significantly higher than in normal pregnancies. Furthermore, it has been shown that artificial and spontaneous abortions can be prevented by treatment, which decreases C1q levels within 7 days (Saitoh et al., 1983).

\section{Non-pregnant female reproductive tract}

Maternal endometrium undergoes cyclic changes regulated by steroid hormones during the menstrual cycle that directs the differentiation of endometrial epithelial and stromal cells crucial for uterine receptivity and implantation for pregnancy (Kannan et al., 2010). The first direct demonstration of SP-D mRNA and protein expression in the uterus suggested the 
possible roles and significance of collectins in innate host defense against pathogens (Madsen et al., 2000). Protein and mRNA expression of SP-A and SP-D have been observed in the female vagina, uterus, ovary, cervix, and oviduct (Table 2, Figure 2) (Akiyama et al., 2002; Oberley et al., 2004; Leth-Larsen et al., 2004). In humans, a strong expression of SP-D in the epithelium of the endometrial glands is observed that increases towards the secretory phase of regular menstrual cycle compared to the proliferative phase (Leth-Larsen et al., 2004). In mouse uterus, SP-D has shown to be hormonally regulated, with peak levels present at estrus, which then decreases at diestrus (Kay et al., 2015). Ovariectomised mice showed significantly reduced expression of SP-D in uteri; following treatment with estrogen and progesterone, SP-D expression increased nine-fold (Kay et al, 2015). Further, treatment with progesterone during diestrus reduced the level of SP-D making them vulnerable to infection (Oberley et al., 2007).

SP-A is reported to be expressed by both pre-and post-menopausal vaginal stratified squamous epithelium and vaginal lavage fluid (MacNeill et al., 2004). Using immunohistochemistry, SP-A expression within the glandular and stromal cells has been observed in the maternal endometrium during the early proliferative phase (day 6-7) of the menstrual cycle. The levels of MBL in the vaginal epithelial cells vary in a cycle-dependent manner with greater changes occurring in the secretory phase of the menstrual cycle. This change, which is associated with progesterone, implicates the protective role of MBL in the female genital tract (Bulla et al., 2010). These findings strongly suggest that cyclic variations in SP-A, SP-D and MBL expression are hormonally regulated.

\section{Amniotic fluid and umbilical cord}

Amniotic fluid (AF) is in constant contact with the fetus throughout pregnancy. It protects and supports fetal development (Underwood et al., 2005). Secretions of soluble immune factors from the fetal lungs travel into the AF (Condon et al., 2004), which is likely to have anti-microbial functions (Underwood et al., 2005). SP-A and SP-D are detected in the AF during the mid-pregnancy and their concentrations significantly increases with advancing gestational age reaching maximum at term (ranging between 1.2 and $15 \mu \mathrm{g} / \mathrm{ml}$ ) (Miyamura et al., 1994). SP-D level gradually increases from $0.11 \mu \mathrm{g} / \mathrm{ml}\left(14-16^{\text {th }}\right.$ week) to $26.3 \mu \mathrm{g} / \mathrm{ml}$ (38$42^{\text {nd }}$ week). SP-A is highly regulated near term; it shows a clear rise from $3 \mu \mathrm{g} / \mathrm{ml}\left(30-31^{\text {st }}\right.$ week) to $24 \mu \mathrm{g} / \mathrm{ml}$ (40-41 ${ }^{\text {st }}$ week) when compared to SP-D (Miyamura et al., 1994). At term ( $39^{\text {th }}$ week), the levels of SP-A and SP-D reach their maximum $4978 \mu \mathrm{g} / \mathrm{ml}$ and $793 \mu \mathrm{g} / \mathrm{ml}$, 
respectively (Miyamura et al., 1994). Thus, changes in the AF levels of SP-A and SP-D can act as a biomarker to assess fetal maturity (Table 3). At term, there is at least 2-fold increase in the levels of SP-A in the umbilical cord blood in newborn babies delivered by spontaneous labor between 36 and 38 weeks $(4.8-50.2 \mathrm{ng} / \mathrm{ml})$ when compared to those delivered through cesarean section i.e., with no labor (2.7-21.7 ng/ml) (Cho et al., 1999).

A similar pattern of increase in the AF level for MBL is observed with advancing gestational age (Malhotra et al., 1994); however, it varies significantly before and after 35 weeks of gestation ( $304 \mu \mathrm{g} / \mathrm{ml}$ and $1070 \mu \mathrm{g} / \mathrm{ml}$, respectively) compared to the serum level of MBL (995 $\mu \mathrm{g} / \mathrm{ml})$ (Malhotra et al., 1994) (Table 3). The C1q level in AF is less than 0.5 $\mu \mathrm{g} / \mathrm{ml}$ compared to its level in the plasma ( $80 \mu \mathrm{g} / \mathrm{ml}$ ) (Miyamura et al., 1994). The level of fetal MBL in the umbilical cord blood (venous and artery $0.70 \mu \mathrm{g} / \mathrm{ml}$ ) is low when compared with the maternal peripheral blood before elective cesarean section $(1.11 \mathrm{mg} / \mathrm{ml})$ (Kielgast et al., 2003; Oudshoorn et al., 2008). The gestational age-dependent changes in the AF levels of collectins may have distinct roles at different stages of pregnancy and parturition in addition to a protective role against infection and inflammation.

\section{Pregnant uterus (amnion, chorion, decidua, myometrium and placenta)}

SP-A and SP-D are present in the human fetal membranes, amniotic epithelium and chorionic membrane (Han et al., 2007), the chorio-decidual layer of the late pregnant uterus (Miyamura et al., 1994), trophoblast of late normal placental villi, early human placenta (Sati et al., 2010), cytotrophoblast, intermediate trophoblast, and syncytiotrophoblast of early gestation (Miyamura et al., 1994; Leth-Larsen et al., 2004) (Table 2; Figure 3). Cytotrophoblasts and mesenchymal cells have been shown to express MBL during early pregnancy (Kilpatrick et al., 1995; Yadav et al., 2016). MBL is synthesized by human term placenta and decidua (Yadav et al, 2014). Complement-activating natural $\mathrm{IgG}$ is found deposited on the placental tissues (Richani et al., 2005; Bulla et al., 2008). Both early (C1q and C4) and late (C5, C6, C9) complement components are seen in the placenta. C1q is widely distributed around the fetal vessels, spiral arteries, trophoblast, decidual endothelial cells, and extravillous trophoblasts (EVT) (Figure 2 and 3) (Bulla et al., 2008, 2009; Agostinis et al., 2010). We recently showed the expression of SP-A, SP-D and C1q in early human decidua specifically on stromal cells and EVT by immunohistochemistry. Transcripts of A, B and C chains of C1q were also detected in early human decidual stromal cells (Madhukaran et al., 2015a). SP-A and SP-D are synthesized by human term and first trimester placental and decidual tissues 
(Yadav et al, 2014; Yadav et al, 2016). As the expression of collectins in gestational tissues is established, an underlying role that directs cellular processes and other signaling pathways in pregnancy needs to be examined.

\section{Role of collectins and C1q in early pregnancy}

Recently, the expression and localization of SP-A, SP-D and C1q was examined in human decidua within the decidual trophoblast and stromal cells (DSCs) (Bulla et al., 2009; Madhukaran et al., 2015a). There is evidence to suggest that transcription factor PU.1 regulates the decidual expression of C1q in early pregnancy (Madhukaran et al., 2015b). This suggests that C1q, regulated by PU.1, may be a critical factor in trophoblast and stromal cell development (differentiation and proliferation) at the feto-maternal interface.

Our preliminary analysis using triple immunofluorescent staining identified trophoblast (verified by intracellular marker cytokeratin 7, CK-7) exhibiting the expression of PU.1 and C1q within the first trimester decidual cells (Figure 4). A considerable percentage of the decidual cells stained for trophoblasts and cytoplasm of trophoblasts were positive for C1q. In addition, PU.1 positive cells accounted for $70-80 \%$ of trophoblasts expressing C1q, pointing to considerable variation in the localization of PU.1 in the nucleus and cytoplasm of the trophoblasts. These data suggest that cytoplasmic localization of PU.1 widespread in the cells of trophoblast lineage might be essential for regulating the cross-talk between trophoblast and C1q function throughout gestation and for mediating immunotolerance and implantation. Understanding the role of PU.1 expression on trophoblast lineage development can have a significant impact on the immunotherapy for adverse pregnancy such as abortion, miscarriage, and preeclampsia (PE) (Madhukaran et al, unpublished). Our study validates a previous report showing that $\mathrm{C} 1 \mathrm{q}$ localizes to the EVT and promotes its invasion, spiral artery remodeling and normal placentation at the feto-maternal interface (Singh et al., 2011). Further, the evidence that C1q produced by decidual endothelial cells (DECs) suggests that it acts as a link between the endovascular trophoblasts and spiral artery endothelial cells, involving the MAP kinase pathway via $\mathrm{gC1qR}$, a receptor for the globular head region of C1q (Bulla et al., 2008; Agostinis et al., 2010; Agostinis et al., 2012).

SP-D levels in the uteri progressively decrease from 0.5 days post coitus (dpc) to 2.5 dpc during early pregnancy, suggesting relevance of uterine SP-D in peri-implantation period in mice (Kay et al, 2015). SP-D gene deficient mice showed significantly increased preimplantation loss, leading to a considerably reduced litter size (Kay et al, 2016, unpublished). 
During spontaneous abortion, SP-A was significantly downregulated while SP-D was upregulated at the feto-maternal interface (Yadav et al, 2016).

There is a paucity of information regarding the role of SP-A and SP-D in early human pregnancy. A prospective (pilot) study was carried out in decidua obtained from 17 pregnant women: 12 with normal pregnancy undergoing elective termination of pregnancy between $7^{\text {th }}$ to $10^{\text {th }}$ week of gestation and 5 with a history of miscarriages (2 samples from early pregnancy and 3 from after labor). Expression of SP-A1, SP-A2, SP-D, C1q A, C1q B, and $\mathrm{C} 1 \mathrm{qC}$ was measured in both groups at week 7, 8, 9, 10, 39 and after labor. The levels of SP$\mathrm{A} 1$ and $\mathrm{C} 1 \mathrm{qB}$ during early gestation (Week 7-10) were significantly higher in women with normal pregnancy (Figure 5 A) and recurrent pregnancy loss (RPL) case (39+1) with a history of 2 miscarriages (Figure 5B). The number of human decidua needs to be increased to prove the statistically significant differences in expression of SP-A1, SP-A2, SP-D, C1qA, $\mathrm{C} 1 \mathrm{qB}$ and $\mathrm{C} 1 \mathrm{qC}$ genes in human decidua (Madhukaran et al, unpublished). Thus, evaluating the gene expression of collectins and $\mathrm{C} 1 \mathrm{q}$ can be clinically significant for predicting the outcome of pregnancy. Our studies provide considerable evidence that the human SP-A1 and $\mathrm{C} 1 \mathrm{qB}$ are associated with normal and complicated pregnancy, but their functional significance is not yet known. It is likely that SP-A1 might play a role in influencing immunosuppressive properties on T-lymphocytes. It has been earlier shown that an interaction between SP-A1 and TGF- $\beta$ triggers immunosuppressive effect on IL-2 secreted by $\mathrm{T}$ lymphocytes (Kunzmann et al., 2006).

MBL was first observed in the endothelial cells and Hofbauer cells (placental macrophages) in the first trimester placenta. Within the decidua, endovascular trophoblasts and endothelial spiral arteries express MBL (Kilpatrick et al., 1995). The increased MBL level in the maternal blood and serum during early normal pregnancy (first trimester) appears to suggest an involvement of MBL in normal placentation and establishment of pregnancy (van de Geijn et al., 2007a).

The ability of SP-A, SP-D, MBL and C1q to act as opsonins confirms enhanced opsonization and phagocytosis of recognized pathogens thus contributing to the innate immune response (Nauta et al., 2004; Kishore et al., 2006). All these properties makes it possible to suggest that the expression of collectins and C1q in early gestational tissues may have a wide range of protective functions, including eliminating pathogens, apoptotic materials, and simultaneously, modulating the immune response during early pregnancy, all of which require further investigation. While the significance of collectins in parturition has been of intense focus over the past decade, the importance of collectins in implantation, 
immune tolerance, regulation of normal placental development and function, regulation of trophoblast invasion, differentiation, proliferation and migration remain to be investigated. In addition, there have been no reports on gestational tissue-specific functions of SP-A, SP-D, MBL and C1q in early pregnancy.

\section{Collectins and C1q in parturition and complicated pregnancy}

Parturition is an inflammatory process and is associated with significant upregulation of SPA, SP-D and MBL levels in AF, with advancing gestational age (Miyamura et al., 1994). Any mutations, SNPs, unusual expression or deficiency involving SP-A, SP-D, MBL, or C1q can be associated with pregnancy complications. Multiple etiologies for various pregnancy complications have been described; however, over one-half of the cases remain unexplained. Although the physiology of pregnancy, initiation and regulation of parturition in human and mice are quite distinct (Bezold et al., 2013), studies using murine models, deficient or overexpressing genes, have been used to understand the role of SP-A, SP-D, MBL or C1q in pregnancy.

\section{$S P-A$ and $S P-D$}

SP-A, SP-D and MBL level reaches maximum at term in AF, which suggests its association with pregnancy maintenance and parturition. Parturition is marked by local production of numerous factors including pro-inflammatory cytokines and hormones (glucocorticoids and PGF2 $\alpha$ ) (Myatt and Sun, 2010). Expression of SP-A in mouse fetal lungs (after $17 \mathrm{dpc}$ ) and its secretion in AF provide a signal for initiation of parturition (Condon et al., 2004; Mendelson and Condon, 2005). Gestational increase in the AF SP-A level augments the production of IL-1 $\beta, N F-\kappa B$ and PGF2 $\alpha$ and infiltration of AF macrophages into fetal membrane, myometrium, uterus and cervix, which probably serve as a signal for labor (Condon et al., 2004). In pregnant mice, intra-amniotic injection of purified SP-A at $15.5 \mathrm{dpc}$ stimulates IL-1 $\beta$ production, leading to preterm delivery within 6-24 hr (Figure 6). Conversely, injecting anti-SP-A antibodies into the mice amniotic sac can delay parturition by up to 24 hours (Condon et al., 2004). The view by Condon et al. that fetal SP-A triggers the onset of labor is consistent with our recent finding that SP-A and SP-D levels are low during pre- $(17.5 \mathrm{dpc})$ and near $(19.5 \mathrm{dpc})$ parturition in the murine decidua (Madhukaran et al., 2015c). Despite the elevated SP-A and SP-D levels in the AF at term, the transcript level of decidual (maternal) SP-A was absent. The withdrawal of decidual SP-A might be responsible for controlling the functional activation of fetal-derived SP-A which regulates 
parturition at term by two different pathways: the endocrine pathway where SP-A in the fetal circulation reaches the placenta and the uterus directly, or with the support of maternal SP-A produced before term. In the paracrine pathway, the fetal lung-derived SP-A enters the AF to exert its effect by increasing AF concentration $\left(26^{\text {th }}\right.$ week to $32^{\text {nd }}$ week) on the fetal membrane (amnion and chorion) to transmit the signal to the myometrium and cervix for the initiation of labor. A better understanding of the role of the fetal SP-A in signalling parturition is required to define the association of fetal and maternal SP-A in parturition. This will also enable us to recognize and prevent the inflammatory responses stimulated in various pregnancy complications

In contrast, SP-D levels were found to decrease with the gestation age from $17.5 \mathrm{dpc}$ to $19.5 \mathrm{dpc}$ in murine decidua (Madhukaran et al., 2015c). We suspect that increased SP-D level at $17.5 \mathrm{dpc}$ could reflect paracrine effect on fetal membrane, cervix and myometrium involved in hindering prostaglandin E2 activation required for labor. The subsequent decrease in SP-D at $19.5 \mathrm{dpc}$ might be functional withdrawal of SP-D prerequisite for upregulation of PGE2, cyclo-oxygenase enzyme-2 (COX2) and increased myometrial sensitivity to estrogen in association with labor process. Altogether, SP-A and SP-D in decidua indirectly regulate parturition. We also demonstrated the host defense role for SP-A and SP-D in the decidua at term, which has the ability to inhibit the release of TNF- $\alpha$ upon LPS challenge, as an indicator of intrauterine infection preventing preterm labor and birth (Madhukaran et al., 2015c).

Before labor, decidual SP-A is highly expressed when compared to the levels in those with labor. Surprisingly, SP-A-induced $(100 \mu \mathrm{g} / \mathrm{ml})$ pro-inflammatory soluble factors (IL-6, IL-8, TNF- $\alpha$, IL-1 $\beta$, MCP-1, MMP-3 and VEGF) did not exhibit any significant difference in stromal cells (Snegovskikh et al., 2011). Additionally, detailed investigation of prostaglandin (PGF2 $\alpha$ ) production revealed that the presence of SP-A in the endometrium selectively inhibits PGF2 $\alpha$ production, suggesting that endometrial SP-A expression may specifically regulate prostaglandins during labor (Snegovskikh et al., 2011). In human myometrial cells, SP-A from the fetal membrane induces actin stress fibre formation by controlling F-actin filament organization, suggesting that SP-A regulates the initiation and maintenance of uterine contraction (of smooth muscle cells) for labor (Garcia-Verdugo et al., 2008; BreuillerFouché et al., 2010; Sotiriadis et al., 2015).

Despite strong indications that SP-A is an important signal linked with parturition, little is known about the underlying molecular events. Moreover, fetal macrophages were not found in the maternal tissue (myometrium) at term (Kim et al., 2006) and SP-A gene- 
deficient mice were able to go into spontaneous labor (Korfhagen et al., 1998; Montalbano et al., 2013). Subsequent studies proved SP-A to be anti-inflammatory (Figure 6). In vitro interaction of AF SP-A with human placental amnion has been proposed to down-regulate the expression of IL-1 $\beta$, CXCL2 and CXCL5, a mechanism essential for initiation of parturition (Lee et al., 2010). Injection of SP-A into the extra-amniotic space within the uterus exposed the anti-inflammatory role of fetal lung SP-A with downregulated expression of inflammatory molecules (IL-1 $\beta$, TNF- $\alpha, \mathrm{NF}-\kappa \mathrm{B}$ and CCL5) via TLR2 in the placenta and fetal tissues. Simultaneously, SP-A was shown to enhance the expression of antiinflammatory molecules (CXCL1 and IL-10) within the placental, fetal and uterine tissues that can prolong the gestation (Agrawal et al., 2013). A recent study has examined inflammatory and contractile genes from mice deficient in SP-A or SP-D. Prolonged gestation was observed for $\sim 10-12 \mathrm{hrs}$ in SP-A deficient mice $\left(2^{\text {nd }}\right.$ and $3^{\text {rd }}$ litter) with reduced levels of IL- $1 \alpha$, IL- $1 \beta$ and IL- 6 in the myometrium compared to the wild-type mice. Furthermore, the expression of contractile genes (oxytocin receptor and connexin-43) was not significantly higher than control delaying parturition (Montalbano et al., 2013). Induction of oxytocin receptor (OXTR) and connexin 43 (CX43) expression and secretion of GRO $\alpha$ (chemokine CXCL1) and IL-8 by the myometrial cell line, ULTR, following treatment with SP-A and SP-D provides further evidence that the two collectins play a key role in modulating events prior to labour by reconditioning the human myometrium and thus shifting the uterus from a quiescent to a contractile state (Sotiriadis et al., 2015).

The association of transcription factor, Forkhead box M1 (FOXM1), with lung maturity and expression of SP-A has been examined in an animal study. FOXM1 was utilized for studying the fetal lung development due to its regulatory functions related to cellular proliferation, differentiation, vascular remodelling and metabolism. The study found that as FOXM1 (mRNA and protein) expression increased, SP-A (mRNA) expression decreased in rabbit fetal lungs (Hahn et al., 2013). A significant delay in parturition of nearly $38 \mathrm{hrs}$ has been recently reported in steroid receptor coactivators 1 and 2 (SRC-1 and SRC-2) doubledeficient mice with reduced expression of NF- $\kappa \mathrm{B}, \mathrm{PGF} 2 \alpha$, and contractile genes (oxytocin receptor, connexion-43, cyclooxygenase 2, prostaglandin-endoperoxide synthase 2), SP-A, lysophosphatidylcholine acyltransfereae-1 (LPCAT-1), pro-inflammatory glycerophospholipid and platelet-activating factor (PAF) in near term fetal lungs, maternal myometrium and in fetal AF (Gao et al., 2015). Exogenous injection of SP-A (3 $\mu \mathrm{g} / \mathrm{sac}$ ) or PAF $(0.25 \mathrm{ng} / \mathrm{sac})$ into the amnion of SRC-1/2- deficient mice at $17.5 \mathrm{dpc}$ activated the 
downstream signals in parturition cascade by enhancing NF- $\mathrm{B}$ and contractile genes. SP-A or PAF injection lowered both steroidogenic acute regulatory protein (StAR) and P4 in circulation (Gao et al., 2015). This correlation between SRC-1/2 and SP-A or PAF expression highlights fetus signal in parturition. Therefore, maturation of fetal lungs and SP-A secreted from lungs may be used as a potential marker for forecasting lung maturity and survival of the fetus by generating a signal to initiate labour at term. The importance of SP-D in parturition has also been shown by the finding that methionine allele SP-D gene polymorphism (methionine allele, Met31Thr) in the fetus is associated with spontaneous preterm birth within the Northern Finland population (Karjalainen et al., 2012).

Since SP-A serves as a key signal molecule for initiation of parturition, levels of AF SP-A at term in labor (spontaneous human parturition) and without labor have been measured. AF SP-A level was shown to decrease $(1.2-10.1 \mu \mathrm{g} / \mathrm{ml})$ in spontaneous labor at term when compared to women not in labor (2.2-15.2 $\mu \mathrm{g} / \mathrm{ml})$ (Chaiworapongsa et al., 2008b). However, an insignificant difference in the levels of SP-A was observed in maternal serum before and after labor (Cho et al., 1999). The biological significance of placental SP-A, SP-D and MBL in parturition is further supported by the altered levels of SP-A, SP-D and MBL in spontaneous term labor (Yadav et al., 2014). Another study using SP-A or SP-D overexpressing mice has shown that maternal challenge with an increasing concentration of LPS (intraperitoneal injection of smooth LPS) from $17 \mathrm{dpc}$ till term $(12 \mu \mathrm{g}, 15 \mu \mathrm{g}, 20 \mu \mathrm{g}$ and 25 $\mu \mathrm{g} /$ mouse) modulates the LPS-induced cytokine response within the mother and the fetus inducing spontaneous preterm labor (Figure 6). Increased expression of TNF- $\alpha$ and IL-10 in AF and fetal membrane was detected when compared to the wild type controls (Salminen et al., 2008, 2011, 2012). Thus, higher SP-A or SP-D concentrations do not correlate with the timing of labor, but instead, they increase the risk of preterm birth and fetal mortality. It is likely that an increase in maternal SP-A or SP-D levels during infection induced preterm labor can be a useful marker to predict the outcome of pregnancy, though it would require extensively planned, large clinical studies.

\section{$M B L$}

Very little is known about the role of MBL in parturition. Due to the increase in the level of MBL in first trimester till term with sharp decrease after delivery, MBL is believed to be involved in the parturition process and onset of labor. MBL-2 gene polymorphism has been reported to affect the immunological events in normal pregnancy. The presence of MBL-2 
gene polymorphism is beneficial at times but not in all cases, as it is also associated with complicated pregnancies. In immunocompromised women with genetic polymorphisms and low levels or deficiency of MBL during mid-pregnancy are related to functional changes in the placenta; in particular, placental lesions, placental insufficiency, and inflammatory infiltrates are associated with low gestational age and low birth weight (van de Geijn et al., 2008), recurrent abortions, idiopathic recurrent late pregnancy loss (Christiansen et al., 2009), unexplained recurrent miscarriages (Christiansen et al., 2002; 1999; 2009; Kruse et al., 2002), chorioamnionitis, and PE (van de Geijn et al., 2007b; Holmberg et al., 2008). There is also an increased expression of MBL in uterine lumen during oocyte collection in patients with unexplained infertility when compared to tube infertility patients (Oger et al., 2009).

Bodamer et al. have examined polymorphisms in the coding and promoter regions of MBL-2 in premature infants. In particular, codon 52 was demonstrated to have a significant association with the group of infants born preterm (before 36 weeks) compared with the infants born at term (Bodamer et al., 2006). In a correlation study between MBL levels and recurrent miscarriage, a low level of serum MBL $(0.1 \mathrm{mg} / \mathrm{ml})$ was observed in blood samples obtained from both male and female partners with recurrent miscarriage (Kilpatrick et al., 1996, 1999). Furthermore, decreased MBL levels at the feto-maternal interface have been reported to be insufficient to regulate infection-induced inflammatory response leading to fetal loss (Kilpatrick et al., 1995). Taken together, maternal gene polymorphisms (Codon 52 and Codon 54) with low MBL serum levels pose greater risk to the fetus by increasing susceptibility to infection. The pro-inflammatory reactions induce preterm labor and birth (< 29 weeks) with reduced weight owing to reduced fetal growth and development. Further studies are thus required to identify the role of fetal variant MBL genotype in causing premature delivery and preterm birth. In contrast, others reported that MBL-2 genotypes on promoters MBL variants $(-550 \mathrm{C}>\mathrm{G}$ and $-221 \mathrm{G}>\mathrm{C})$ and structural $\mathrm{MBL}$ variants with missense mutation (R52C, G54D, G57E) in exon 1 with low levels of MBL did not contribute or influence unexplained recurrent pregnancy loss or miscarriage (Baxter et al., 2001; Berger et al., 2013).

In the gene encoding MBL, six SNPs are identified at position -550 H/L (G/C) and $221 \mathrm{X} / \mathrm{Y}(\mathrm{C} / \mathrm{G})$ in the promoter region, $+4 \mathrm{P} / \mathrm{Q}(\mathrm{C} / \mathrm{T})$ in the translated region. Three polymorphisms located in exon 1 at codon $52 \mathrm{~A} / \mathrm{D}(\mathrm{Arg} \rightarrow \mathrm{Cys})$, codon $54 \mathrm{~A} / \mathrm{B}(\mathrm{Gly} \rightarrow \mathrm{Asp})$ and codon $57 \mathrm{~A} / \mathrm{C}(\mathrm{Gly} \rightarrow \mathrm{Glu})$. The SNPs in promoter region at position -550 and -221 form four haplotypes HY, LY, LX, HX out of which 7 coding variants are observed -HYPA, LXPA, LYQA, LYPA, HYPD, LYPB and LYOC (Madsen et al., 1995, 1998). High MBL 
levels in serum have been demonstrated to have pro-inflammatory properties against the fetus resulting in preterm labor. Maternal serum from women undergoing normal deliveries had high fetal MBL genotype levels (H/L)YA/(H/L)YA and (H/L)YA)/LXA associated with a significantly shorter gestational age (before 29 weeks of gestation) when compared with intermediate (LXA/LXA and (H/L)YA/O) and low (LXA/O and O/O) MBL serum genotype group. Approximately $13 \%$ of the fetuses delivered were of high MBL serum genotype levels while 3\% were intermediate and low MBL serum genotype groups (van de Geijn et al., 2008).

In normal pregnancy, EVT invades the decidua until it reaches the inner third of the myometrium and the extent of trophoblast invasion therefore needs to be regulated. Inadequate tapering of maternal arteries and improper trophoblast invasion is associated with PE (Rodeck and Whittle, 2009). PE is a common pregnancy disorder characterized by abnormal placental function, hypertension, and proteinuria. Several studies have attempted to associate MBL levels and MBL genotypes with PE; most of them showed functional association of MBL levels with PE pathogenesis. In a comparative study, plasma from pregnant women with and without PE were examined by proteomic analysis. Wang et al. did not find any significant association between MBL levels in plasma and PE compared with normal pregnancies (Wang et al., 2007). Similarly, a high frequency of maternal MBL genotype ( 3 structural and 2 promoter polymorphisms) did not show any association with PE (van de Geijn et al., 2007b).

The gene polymorphisms of MBL-2 gene in the structural region as well as promoter region that contribute to low levels of MBL showed a significant association with the pathogenesis of PE in Brazilian women (Vianna et al., 2010). Maternal MBL-2 genotype (variant B allele, codon 54) is implicated in a protective role against the development of PE and PE-associated intrauterine growth restriction (IUGR) via complement activation (Figure 7). The frequency of MBL-2 gene polymorphism compared between women with PE and full term controls were examined. Importantly, higher MBL-2 genotype levels were detected in PE women ( 86-95\%) compared to full-term controls ( 70-83\%) (Sziller et al., 2007a). Excessive lectin pathway activation and an increase in placental MBL levels are likely to impair trophoblast invasion and spiral arteries formation, resulting in activation of hypoxic signaling pathway related to PE (Girardi et al., 2006). With an increase in maternal MBL-2 genotype activity, their ability to activate complement is affected, as low serum MBL levels are unable to interact with MASPs, thus protecting the placenta against development of PE. Maternal variant A (wild type allele) in codon 54 of MBL2 has been proposed to increase 
MBL levels in serum that is associated with the development of PE (Figure 7). Recently, Agostinis and colleagues implicated MBL as a major protein found to be increased in the sera obtained from PE patients, which is potentially responsible for inhibiting the cell communication between fetal trophoblasts and decidual endothelial cells preventing trophoblast invasion (Agostinis et al., 2010). This is consistent with the findings in earlier studies in which C1q expressed by decidual cells (endothelial cells and trophoblasts) was shown to enhance the cross-talk between fetal trophoblasts and decidual endothelial cells essential for trophoblast migration and invasion, spiral artery formation, vascular remodeling and placental development (Bulla et al., 2008; Agostinis et al., 2010). The best evidence for protective role of MBL has come from studies of abortion-prone mouse model (CBA/J X $\mathrm{DBA} / 2$ ) of PE. MBL-A has been detected at the early stages of pregnancy (3.5dpc) while MBL-A deficiency demonstrated to prevent pregnancy loss. Furthermore, DBA/2-mated $\mathrm{CBA} / \mathrm{J}$ mice were able to prevent fetal loss efficiently after polyman2 (mannosylated molecule that binds to MBL-A with high affinity) treatment (Petitbarat et al, 2015). Thus, increased levels of MBL in PE may contribute to the failure of the endovascular invasion of trophoblast cells.

In another study, however, no systematic functional activity of MBL-MASP2 levels were found to correlate with the disease onset, severity, fetal growth restriction, or birth weight linked to PE (Csuka et al., 2010). The study classified PE and normal pregnant participants into three groups, namely MBL deficient, MBL normal and MBL high. Importantly, complement activation was relatively higher in both MBL high as well as MBL deficient categories. It is speculated that altered (both low and high) levels of MBL can give rise to dysregulated complement activation, thus contributing to PE (Csuka et al., 2010). This may explain why some of the studies did not find a significant association of PE with MBL levels. It is likely that deficiency or low levels of MBL in pregnancy probably lead to accumulation of apoptotic cell debris, excessive inflammatory responses, and an enhanced production of autoantibodies, resulting in adverse pregnancy outcomes. In the case of IUGR neonates at birth, the concentration of MBL level in the cord blood remains significantly low, confirming that altered levels of MBL contribute to adverse pregnancies (Briana et al., 2012). Given that IUGR neonates are more susceptible to infections, MBL's role in host defense in these neonates is easy to understand. Therefore, altered serum MBL levels can be useful as a biomarker for spontaneous abortion, PE and IUGR. 


\section{$C 1 q$}

C1q deficiency is associated with improper placental formation, trophoblast invasion, impaired angiogenic balance and an increased risk of fetal death resulting in miscarriages, preterm delivery, and PE (Agostinis et al., 2010; Singh et al., 2011). Lower concentration of anti-C1q antibodies and higher levels of IL-15 have been observed in ectopic pregnancies and missed abortions when compared to complicated pregnancies (Daponte et al., 2013). Storelli et al. have reported that mothers exposed to polychlorinated biphenyls (PCBs) are at a higher risk of spontaneous miscarriage, stillbirth and fetal resorption (Storelli et al., 2011). Decidual levels of $\mathrm{gC1qR}$ correlate with enhanced PCBs content in plasma in mothers who underwent spontaneous abortion (Gu et al., 2012). Reduced percentage of apoptotic cells were observed in human trophoblast cell line treated with PCBs compared with cells treated with PCBs and $\mathrm{gC1qR}$ small interfering RNA (Gu et al., 2012). This upregulation of $\mathrm{gClqR}$ may have evolved as a defense mechanism to reduce damage to the human trophoblast cells exposed to PCBs resulting in complicated pregnancies.

Villitis of unknown etiology (VUE) is a complication of pregnancy characterized by inflammation in the chorionic villi. It can be caused by either maternal infection or when placental tissues are affected by immune system i.e. NK cell attack via cytotoxic $\mathrm{T}$ cells (Tamblyn et al., 2013). Distribution of C1q has been observed in the placenta with VUE and within the stroma of inflamed villi suggesting an important contribution of C1q in Villitis (Altemani et al., 1992).

Human placentae (20 normal and $20 \mathrm{PE}$ ) were studied by immunofluorescence for the presence of complement components; $\mathrm{Clq}$ was increased in PE as compared to normal tissues (Sinha et al, 1984). C1q knock-out mice are known to show a defect in the clearance of apoptotic cells and developed glomerulonephritis (Botto et al, 1998). This study hinted that C1q deficiency might be responsible for accumulation of apoptotic trophoblasts in the pathogenesis of PE. An association of the absence or low levels of C1q in PE patients was recently shown (Agostinis et al., 2010). Subsequent studies confirmed that C1q deficient mice develop symptoms similar to PE; these features include hypertension, albuminuria, endotheliosis, decreased placental VEGF, increased soluble VEGF receptor 1 (sFlt-1), increased oxidative stress, decreased blood flow, increased fetal death, diminished litter size, abnormal invasion of trophoblasts, and increased levels of STAT-8 (inhibitor of trophoblast migration) (Singh et al., 2011). However, in one of the studies, C1q mRNA expression at placenta was not different between PE women and normal controls (Burma et al, 2012). Syncytiotrophoblast microvesicles (STBM) are pro-inflammatory and circulate in increased 
amounts in $\mathrm{PE}$ women and $\mathrm{C} 1 \mathrm{q}$ was observed to be one of the 538 proteins unique to $\mathrm{PE}$ STBM (Tanetta et al, 2012). Interestingly, a recent study was able to relate C1q deposits that occur in early onset of PE placenta, with immune tolerance and clearance of apoptotic cells. The authors have observed more $\mathrm{Clq}$ deposition in endothelial stroma, large villi and fibrinoid necrotic areas in the placenta of early onset than in late onset PE women. Additionally, C1q deposit areas had C4bp protein binding to apoptotic fragments and trophoblastic syncytium knots (Lokki et al., 2014). These data suggest that C1q, with C4bp factor released from placenta, may be responsible for immune tolerance by promoting clearance and phagocytic uptake of apoptotic trophoblast cells accumulated in the PE placenta. Association of both low and high C1q levels with PE suggests that any dysregulation in $\mathrm{C} 1 \mathrm{q}$ levels may lead to anomalous placental development. .

It is evident now that SP-A, SP-D, MBL and C1q have a regulatory role in pregnancy maintenance and parturition. However, there is yet a lack of clarity on the underlying mechanisms and roles of these proteins in different phases of pregnancy. Once we have this understanding, it may help devise strategies to ameliorate or prevent adverse pregnancy outcomes. Overall, the studies suggest that the regulation of inflammation at the fetomaternal interface is critical, and these molecules, under hormonal influence, are integral to regulation of inflammation. SP-A has the ability to elicit inhibitory or stimulatory response favouring pregnancy maintenance and stimulating parturition driven by maternal or fetal demand, depending on the gestational tissues, receptors and tissue-specific cells. It is difficult to generalize the role of SP-A as an initiator of parturition/contraction due to inconsistency and significant gaps reported so far. However, observational inconsistencies could be due to different endocrine control of parturition in mouse and humans; besides, SP-A could be multifunctional. The underlying mechanism by which fetal or maternal SP-A triggers parturition, evidence for migration of fetal lung specific macrophages into the maternal compartment at term, how these regulatory proteins maintain pregnancy till term although their levels are lower in AF, functional significance of their increase with advancing gestation, hormonal stimulation of fetal lung SP-A triggering myometrial contraction and uterine ripening (SP-A dependent pathway) needs to be examined during pregnancy. Most studies have focussed on parturition and further studies on SP-A, SP-D, MBL and C1q in pregnancy maintenance are required to gain deeper understanding of their roles. 


\section{C1q and collectins in pregnancy associated infections}

During pregnancy, microbial infections of the genital tract by Escherichia coli, Klebsiella pneumonia, Chlamydia trachomatis, Neisseria gonorrhoeae and Trichomonas vaginalis, and intrauterine infection such as chronic hepatitis B virus (HBV), and cytomegalovirus (CMV) cause fetal damage leading to miscarriage, infertility, ectopic pregnancies, preterm labor via pro-inflammatory immune response.

\section{$S P-A$ and $S P-D$}

During intra-amniotic infection (IAI), bacterial LPS lining the outer membrane of Gramnegative bacteria trigger potent pro-inflammatory immune response resulting in chorioamnionitis, preterm labor, and delivery. Hence, the AF gets exposed to several inflammatory molecules, cytokines and soluble factors. The progressive increase of SP-A and SP-D in the AF during pregnancy is likely to have protective role against intrauterine infections by controlling the inflammatory response. Inflammation of the fetal membrane due to bacterial infection (chorioamnionitis) is very common in pregnant women between $26^{\text {th }}$ $32^{\text {nd }}$ week of gestation during which the concentration of SP-A and SP-D are reduced (Lahra and Jeffery, 2004). However, Han et al. found no significant difference in SP-A mRNA expression in the chorioamniotic membrane from women with chorioamnionitis preterm delivery and from those without chorioamnionitis preterm delivery. However, the level of SP-A was increased at term in women with chorioamnionitis compared to spontaneous labor at term (Han et al., 2007). The comparative analysis of AF SP-A and SP-D levels examined in women with and without IAI showed no significant differences between the SP-A/SP-D and IAI infection in the AF (Chaiworapongsa et al., 2008b). Conversely, an excessive increase in SP-A due to maternal infection (bacterial) at term pregnancy has been shown to have a negative effect on pregnancy triggering labor. In animal models, intra-peritoneal administration of LPS on $16-17^{\text {th }}$ day of gestation induces SP-A, but not SP-D, secretion in the uterus at term pregnancy, and initiates parturition (Salminen et al., 2011, 2012). Chlamydia trachomatis infection in the female reproductive tract leads to fallopian tube damage and infertility (Paavonen and Eggert-Kruse, 1999). It has been shown that SP-D, but not SP-A, can inhibit Chlamydia trachomatis infection in a dose dependent manner in the endocervical epithelial cell line (Oberley et al., 2004, 2007). Additionally, SP-A is also attributed to neonatal immunity. Initially, SP-A knock-out mice were found to be more susceptible to LPS induced inflammatory response with high rate of fetal mortality compared to wild type mice. This inflammatory response was reconciled with oral administration of SP- 
A which increased the survival of the fetus (George et al., 2008). In addition, exogenous administration of SP-A or SP-D has also been shown to inhibit LPS mediated TNF- $\alpha$ via decidual macrophages at $17.5 \mathrm{dpc}$. Thus, decidual SP-A and SP-D appear to offer protection against intrauterine infection towards the term (Madhukaran et al., 2015c). The molecular mechanism by which the inflammatory condition is modulated is not understood fully.

\section{$M B L$}

Bacterial vaginosis and vulvovaginal candidiasis infection are the most common threat during pregnancy. During early stages of menstrual cycle, there is a significant change in the vaginal microbial flora within the cervico-vaginal cavity (Romero et al., 2014). MBL, produced by the vaginal cells, are detected in the vaginal lavage along with other normal microflora (Bulla et al., 2010). The polymorphism in MBL2 gene (condon 54) on exon 1 leads to unstable polymeric MBL proteins that are rapidly degraded (Babovic-Vuksanovic et al., 1999). Carriers of this allele have reduced levels of MBL in their circulation and in their vaginal fluid, making them more susceptible to recurrent vulvovaginal candida infection (Babula et al., 2003). Women with Chlamydia trachomatis infection with variant allele A or B at codon 54 in MBL-2 gene are at a greater risk for fallopian tube occlusion than wild type allele A (Sziller et al., 2007b). Low levels of MBL are common in patients with tubal factor infertility, sepsis, and septic shock. However, there seems to be no association between MBL deficient genotype and tubal factor infertility (Laisk et al., 2010, 2011; Wahab Mohamed and Saeed, 2012). Low serum MBL levels can be used as markers for septic shock in mothers and to evaluate the clinical outcome in neonates. MBL-2 gene polymorphism (codon 54, allele B) in the lower genital tract could serve as a marker for predicting Chlamydia trachomatis infection associated with higher risk of fallopian tube damage and early pregnancy loss.

Viral infections such as $\mathrm{HBV}$ and $\mathrm{CMV}$, and $N$. gonorrheae get transmitted from mother to the fetus. These pathogens infect the reproductive tissues such as placenta and chorioamniotic membrane. MBL, an acute phase reactant, is found to be increased in serum after viral infection (Hakozaki et al., 2002). In human pregnancy, maternal HBV promotes increase in fetal MBL, which probably reflects the protective role of MBL in inhibiting intrauterine infection transmission of HBV from the mother to fetus (Wu et al., 2013). Low serum levels of MBL with gene polymorphisms at codon 52 (exon I) and codon 54 (allele B) have been associated with disease progression and poor prognosis of HBV (Thio et al., 2005). In contrast, a high serum level of MBL is linked to patient survival with HBV infection 
(Hakozaki et al., 2002). Although MBL and HBV have been extensively investigated in human pregnancy, the association of MBL polymorphism with prognosis of HBV infection remains controversial. A study by Hohler et al. was unable to establish a connection between MBL polymorphisms and susceptibility to HBV infection (Hohler et al., 1998). Similarly, a recent study on SNPs (rs2120131, rs4935047, and rs7095891) in the MBL-2 gene in the Chinese Han population found no association with the susceptibility to HBV (Zhang et al., 2013). Prenatal and perinatal neonates from CMV infected mother with MBL-2 gene polymorphism when compared with non-infected mothers did not show any increase in the susceptibility of CMV infection (Szala et al., 2011). The conflicting results may be due to patient recruitment (age, race, origin and previous history), different methodology, control samples, comparison studies, limiting within specific population, sample collected during different periods of pregnancy, and sample size. Further studies are needed to clarify the potential impact of MBL-2 polymorphism in intrauterine infection.

There is ample evidence to suggest that Plasmodium falciparum infection plays an important role in pregnancy outcomes. For instances, $P$. falciparum-infected erythrocytes membrane protein-1 (PfEMP1) that has affinity for chondroitin sulfate A were observed to infect the red blood cells by residing in the endothelium lining the intervillous space within the placenta. Additionally, they up-regulate infiltration of inflammatory cells and cytokines response via antigen presenting cells leading to massive chronic intervillositis (MCI), IUGR and premature labor (Fried and Duffy, 1996). Although MBL has been reported to recognize and interact with P. falciparum-infected erythrocytes (Garred et al., 2003), MBL-2 polymorphism at codon 57 in exon 1 showed no association with placental malaria infection with the concentration of MBL or MBL-2 genotypes measured in the intervillous space (Thevenon et al., 2009). MBL could opsonize $P$. falciparum to eliminate the infection through excessive complement activation (Silver et al., 2010) in placental malaria but simultaneously damage the normal placental function (tissue integrity, endothelial activation, vascular remodelling) (Silver et al., 2010). This excess complement activation may alter the pathogenesis of placental malaria leading to tissue hypoxia, enhanced vascular permeability, and improper placental vasculature contributing to adverse pregnancy outcomes. Furthermore, binding of MASP-2 with R439H mutation to MBL also reduces the enzymatic activity due to excessive complement activation (Thiel et al., 2009). This aberrant mutation observed in MASP-2 influences alteration in MBL-2:MASP-2 complex and complement activation (Holmberg et al., 2008, 2012). Thus, the modulatory role of MBL, MASPS-2 and downstream complement activation may suggest MASP-2 for therapeutic purpose. Further 
studies exploring the effects of MBL and MAS-P2 mutations on placental malaria are needed.

$C 1 q$

Intraperitoneal injection of serum resistant $N$. gonorrhoeae pre-incubated with $\mathrm{C} 1 \mathrm{q}$ shows a progressive increase in the infection (6-7 days) in an animal model of gonococcal bacteremia in rat pups (Nowicki et al., 1995). C1q is considered to be involved in clearance of apoptotic debris caused by infection during early pregnancy due to its presence at the feto-maternal interface in decidual endothelial cells (DEC) and trophoblast (Bulla et al., 2008) in normal pregnancy and PE (Lokki et al., 2014). Besides C1q, expression of MYD88, MD2, and TLR4 on DEC also contributes to an anti-inflammatory response at the feto-maternal interface (Masat et al., 2012). This makes C1q an attractive host defence molecule at the feto-maternal interface. Pathogens like Trypanosoma cruzi spread to humans by blood sucking bug Triatominae. It can also infect the decidua (trans-placental) by entering the mother through placenta and chorioamniotic membrane (Shippey et al, 2005). Once T. cruzi is in contact with the host, T. cruzi calreticulin protein (TcCRT; $45 \mathrm{kDa}$ ) moves from the endoplasmic reticulum to the external surface of the parasite. Maternal C1q in the placenta recognizes and binds to CRT entering the host (Ramos et al., 1991). This CRT-C1q interaction prevents the activation of the classical pathway and enhances the spreading of T. cruzi infection (Ferreria et al., 2004; Molina et al., 2005). Thus, C1q has both a protective role as well as detrimental effect in controlling intrauterine infection.

\section{Collectins and C1q in maternal autoimmune disorders}

The most common maternal autoimmune diseases found during pregnancy are autoimmune thyroid disease (AITD), gestational diabetes mellitus (GDM) and rheumatoid arthritis (RA) that cause adverse pregnancy outcomes (Stagnaro-Green et al., 2011).

\section{Autoimmune thyroid disease (AITD) or autoimmune thyroiditis}

Autoimmune thyroid disease is characterized by the stimulation of thyroid glands to secrete more thyroid hormones. The stimulation is due to specific thyroid autoantibodies, thyroid peroxidase (TPO) antibodies (Smallridge et al., 2000). Generally, the presence of maternal TPO antibodies results in neurophysiological dysfunction at the early stages (Pop et al., 1995). In a study of pregnant women, serum MBL level was lower during first trimester and decreased further after delivery in thyroid dysfunction women than in normal controls. On 
the other hand, women who reported to have an increased serum MBL level during first trimester had significantly decreased MBL levels after delivery (Potlukova et al., 2013). It is known that thyroid dysfunction influences the MBL level during pregnancy; consequently the association of MBL deficiency with thyroid dysfunction and the outcome of pregnancy have not yet been explained.

\section{Gestational diabetes mellitus (GDM)}

The primary cause for GDM is the glucose intolerance during pregnancy mainly due to pancreatic $\beta$-cell damage. Tissue damage is caused by the autoantibodies against $\beta$-cell of the pancreas. MBL level in both diabetic and healthy women during pregnancy are decreased (Pertyńska et al., 2001). Subsequent study by same group showed no significant increase in MBL levels in diabetics and healthy pregnant women. But later, statistically significant differences in MBL levels between early and late trimesters in diabetics and healthy pregnant women were observed (Pertyńska et al., 2009). Women with low plasma MBL level and gene polymorphism in MBL2 (G54D) gene have higher risk of developing GDM in second or third trimesters of pregnancy when compared to R52C mutation (Megia et al., 2004). However, levels of MBL level during different gestational stages of pregnancy have not yet been definitively demonstrated in vivo.

\section{Rheumatoid arthritis (RA)}

It is a chronic systemic disease of the joints characterized by the inflammatory changes in the synovial membrane, articular structures and atrophy of bones. During pregnancy, MBL recognizes/binds to agalactosyl $\mathrm{IgG}$ and activates the complement system. By doing so it clears the autoantibodies (IgG) and recruitment of inflammatory cells associated with RA. Thus, the level of agalactosyl IgG is decreased while galactosylation is believed to improve pregnancy associated RA disease condition (van de Gejin et al., 2009). Postpartum decrease in IgG galactosylation and MBL leads to outburst of RA disease (Malhotra et al., 1995). The study by van de Gejin et al. provided further evidence of the dual function of MBL in pregnancy; firstly, on the role of MBL-2 clearing the pathogenic agalactosyl $\operatorname{IgG}$, and secondly, its link with the pathogenesis of RA. Despite their relevance in defence mechanism, MBL genotype has no association with RA disease activity or modification of IgG galactosylation during pregnancy and after delivery (van de Gejin et al., 2011). The studies described above outline the delicate role of MBL exerted during pregnancy-associated 
autoimmune diseases. Their role possibly differs depending on the polymorphism and the type of autoimmune disease.

\section{Conclusion}

Collectins and $\mathrm{C} 1 \mathrm{q}$ are implicated in the immune-cross talk at the feto-maternal interface. Although they appear to increase progressively in the gestational tissues with advancing gestational age, their overall role in pregnancy maintenance and parturition, specific functions at different gestational age is not yet clear in normal and abnormal pregnancy. However, due to their ability to exhibit dual role (protective and detrimental), assigning specific role for each protein in pregnancy is difficult. Hence, further investigations are required to understand the direct cellular and regulatory roles played by collectins and C1q in normal pregnancy. Moreover, events in pregnancy are species-specific; the availability of animal models (gene deficient or over expressing) will enable to gain further insight into the role of soluble immune proteins in pregnancy. The presence of SP-A, SP-D and C1q in early human decidua offers certain clues to future research aimed at their role in immune tolerance, implantation, angiogenesis, trophoblast invasion and tissue remodeling. Apoptosis (inflammatory condition) and the removal of apoptotic cells (anti-inflammatory condition) is a normal vital process taking place throughout pregnancy. The role played by collectins and

$\mathrm{C} 1 \mathrm{q}$ in the clearance of the apoptotic cells during trophoblast invasion of early pregnancy and during parturition is a novel area for further investigation. Studies on SP-A and SP-D polymorphism and structural variants in association with pregnancy need to be investigated. Such studies will help us generate new hypothesis to identify key mechanism inducing immunotolerance. Evaluating the biological significance of C-type lectins in uterine/myometrial contraction, and cervical ripening that triggers contraction will provide us great opportunity to develop therapeutic strategies for adverse pregnancies. 


\section{References}

Agostinis C, Bossi F, Masat E, Radillo O, Tonon M, De Seta F, Tesesco F, Bulla R. 2012. MBL interferes with endovascular trophoblast invasion in pre-eclampsia. Clinical and Developmental Immunology, 484321.

Agostinis C, Bulla R, Tripodo C, Gismondi A, Stabile H, Bossi F, Guarnotta C, Garlanda C, De Seta F, Spessotto P, Santoni A, Ghebrehiwet B, Girardi G, Tedesco F. 2010. An alternative role of C1q in cell migration and tissue remodeling: contribution to trophoblast invasion and placental development. Journal of Immunology. 185(7): 4420-4429.

Agrawal V, Smart K, Jilling T, and Hirsch E. 2013. Surfactant protein (SP)-A suppresses preterm delivery and inflammation via TLR2. PLoS One. 20;8(5): e63990.

Akiyama J, Hoffman A, Brown C, Allen L, Edmondson J, Poulain F, Hawgood S. 2002. Tissue distribution of surfactant proteins A and D in the mouse. Journal of Histochemistry \& Cytochemistry. 50 (7): 993-996.

Altemani AM, Norato D, Baumel C.1992. Immunological studies in placentas with villitis of unknown etiology: complement components and immunoglobulins in chorionic villi. Journal of Perinatal Medicine. 20(2):129-134.

Babovic-Vuksanovic D, Snow K, Ten RM. 1999. Mannose-binding lectin (MBL) deficiency. Variant alleles in a midwestern population of the United States. Annals of Allergy, Asthma \& Immunology.82 (2):134-138.

Babula O, Lazdane G, Kroica J, Ledger WJ, Witkin SS. 2003. Relation between recurrent vulvovaginal candidiasis, vaginal concentrations of mannose-binding lectin, and a mannose-binding lectin gene polymorphism in Latvian women. Clinical Infectious Diseases. 37 (5): 733-737.

Ballard PL, Hawgood S, Liley H, Wellenstein G, Gonzales LW, Benson B, Cordell B, White RT. 1986. Regulation of pulmonary surfactant apoprotein SP 28-36 gene in fetal human lung. Proceedings of the National Academy of Sciences USA. 83 (24):9527- 9531.

Baxter N, Sumiya M, Cheng S, Erlich H, Regan L, Simons A. 2001. Recurrent miscarriage and variant alleles of mannose binding lectin, tumour necrosis factor and lymphotoxin alpha genes. Clinical \& Experimental Immunology. 126(3):529-534.

Berger DS, Merhi Z, Hogge WA, Ferrell RE. 2013. Mannose binding lectin genotypes are not associated with increased risk of unexplained recurrent pregnancy loss. Journal of Assisted Reproduction and Genetics. 30(5), 723-727.

Bezold KY, Karjalainen MK, Hallman M, Teramo K, Muglia LJ. 2013.The genomics of preterm birth: from animal models to human studies. Genome Medicine. 5(4):34.

Bodamer OA, Mitterer G, Maurer W, Pollak A, Mueller MW, Schmidt WM. 2006. Evidence for an association between mannose-binding lectin 2 (MBL2) gene polymorphisms and pre-term birth. Genetics in Medicine, 8(8), 518-524.

Botto M, Dell'Agnola C, Bygrave AE, Thompson EM, Cook HT, Petry F, Loos M, Pandolfi PP, Walport MJ. 1998. Homozygous C1q deficiency causes glomerulonephritis associated with multiple apoptotic bodies. Nature Genetics. 19(1): 56-59.

Breuiller-Fouché M, Dubois O, Sediki M, Garcia-Verdugo I, Palaniyar N, Tanfin Z, Chissey A, Cabrol D, Charpigny G, Mehats C. 2010. Secreted surfactant protein A from fetal membranes induces stress fibers in cultured human myometrial cells. American Journal of Physiology, Endocrinology and Metabolism. 298(6):E1188-1197.

Briana DD, Liosi S, Gourgiotis D, Boutsikou M, Baka S, Marmarinos A, Hassiakos D, Malamitsi-Puchner A. 2012. The potential role of the lectin pathway of complement in the host defence of full-term intrauterine growth restricted neonates at birth. Journal of Maternal- Fetal Neonatal Medicine. 25(5):531-534. 
Bulla R, Agostinis C, Bossi F, Rizzi L, Debeus A, Tripodo C, Radillo O, De Seta F, Ghebrehiwet B, Tedesco F. 2008. Decidual endothelial cells express surface-bound $\mathrm{C} 1 \mathrm{q}$ as a molecular bridge between endovascular trophoblasts and decidual endothelium. Molecular Immunology. 45(9): 2629-2640.

Bulla R, Bossi F, Agostinis C, Radillo O, Colombo F, De Seta F, Tedesco F. 2009. Complement production by trophoblast cells at the feto-maternal interface. Journal of Reproductive Immunology. 82(2):119-125.

Bulla R, De Seta F, Radillo O, Agostinis C, Durigutto P, Pellis V, De santo D, Tedesco F. 2010. Mannosebinding lectin is produced by vaginal epithelial cells and its level in the vaginal fluid is influenced by progesterone. Molecular Immunology. 48(1-3), 281-286.

Buurma A, Cohen D, Veraar K, Schonkeren D, Claas FH, Bruijn JA, Bloemenkamp KW, Baelde HJ. 2012. Preeclampsia is characterized by placental complement dysregulation. Hypertension. 60(5):1332-1337.

Chaiworapongsa T, Hong JS, Hull WM, Kim CJ, Gomez R, Mazor M, Romero R, Whitsett JA. 2008b.The concentration of surfactant protein-A in amniotic fluid decreases in spontaneous human parturition at term. Journal of Maternal- Fetal Neonatal Medicine. 21(9):652-659.

Cho K, Matsuda T, Okajima S, Matsumoto Y, Sagawa T, Fujimoto S, Kobayashi K. 1999. Factors influencing pulmonary surfactant protein A levels in cord blood, maternal blood and amniotic fluid. Biology of Neonate. 75 (2):104-110.

Christiansen OB, Kilpatrick DC, Souter V, Varming K, Thiel S, Jensenius JC.1999. Mannan-binding lectin deficiency is associated with unexplained recurrent miscarriage. Scandinavian J of Immunology. 49 (2):193196.

Christiansen OB, Nielsen HS, Lund M, Steffensen R, Varming K. 2009. Mannose-binding lectin-2 genotypes and recurrent late pregnancy losses. Human Reproduction. 24(2):291-299.

Christiansen OB, Pedersen B, Rosgaard A, Husth M. 2002. A randomized, double-blind, placebo-controlled trial of intravenous immunoglobulin in the prevention of recurrent miscarriage: evidence for a therapeutic effect in women with secondary recurrent miscarriage. Human Reproduction. 17 (3):809 - 816.

Condon JC, Jeyasuria P, Faust JM, Mendelson CR. 2004. Surfactant protein secreted by the maturing mouse fetal lung acts as a hormone that signals the initiation of parturition. Proceedings of the National Academy of Sciences USA. 101 (14):4978-4983.

Crouch E, Rust K, Veile R, Donis-Keller H, Grosso L. 1993. Genomic organization of human surfactant protein D (SP-D). SP-D is encoded on chromosome 10q22.2-23.1. The Journal of Biological Chemistry. 268 (4): 29762983.

Crouch E, Persson A, Chang D, Heuser J. 1994. Molecular structure of pulmonary surfactant protein D (SP-D). The Journal of Biological Chemistry. 269 (25): 17311-17319.

Csuka D, Molvarec A, Derzsy Z, Varga L, Füst G, Rigó J, Prohászka Z. 2010. Functional analysis of the mannose-binding lectin complement pathway in normal pregnancy and preeclampsia. Journal of Reproductive Immunology. 87(1-2), 90-96.

Daponte A, Deligeoroglou E, Pournaras S, Hadjichristodoulou C, Garas A, Anastasiadou F, Messinis IE. 2013. Interleukin-15 (IL-15) and anti-C1q antibodies as serum biomarkers for ectopic pregnancy and missed abortion. Clinical and Developmental Immunology. 2013:637513.

Degn SE, Jensen L, Hansen AG, Duman D, Tekin M, Jensenius JC, Thiel S. 2012. Mannan-Binding LectinAssociated Serine Protease (MASP)-1 Is Crucial for Lectin Pathway Activation in Human Serum, whereas neither MASP-1 nor MASP-3 is required for alternative pathway function. The Journal of Immunology. 189(8):3957-3969.

Eliakim R, Goetz GS, Rubio S, Chailley Heu B, Shao JS, Ducroc R, Alpers DH. 1997. Isolation and characterization of surfactant-like particles in rat and human colon. The American Journal of Physiology. 272(3 Pt 1), G425-G434. 
Epstein J, Eichbaum Q, Sheriff S, and Ezekowitz RA.1996. The collectins in innate immunity. Current Opinion in Immunology. 8 (1): 29-35.

Ezekowitz RA, Day LE, Herman GA. 1988. A human mannose-binding protein is an acute-phase reactant that shares sequence homology with other vertebrate lectins. The journal of experimental medicine. 167 (3): 10341046.

Farber K, Cheung G, Mitchell D, Wallis R, Weihe E, Schwaeble W, Kettenmann H. 2009. C1q, the recognition subcomponent of the classical pathway of complement, drives microglial activation. Journal of Neuroscience Research. 87 (3):644-652.

Ferreira V, Valck C, Sanchez G, Gingras A, Tzima S, Molina MC, Sim R, Schwaeble W, Ferreira A. 2004. The classical activation pathway of the human complement system is specifically inhibited by calreticulin from Trypanosoma cruzi. Journal of Immunology. 172 (5): 3042-3050.

Fried M, and Duffy PE. 1996. Adherence of Plasmodium falciparum to chondroitin sulfate A in the human placenta. Science 272 (5267):1502-1504.

Gao L, Rabbitt EH, Condon JC, Renthal NE, Johnston JM, Mitsche, MA, Chambon P, Xu J, O'Malley BW, Mendelson CR. 2015. Steroid receptor coactivators 1 and 2 mediate fetal-to-maternal signaling that initiates parturition. The Journal of Clinical Investigation. 125(7), 2808-2824.

Garcia-Verdugo I, Tanfin Z, Dallot E, Leroy MJ, Breuiller-Fouché M. 2008. Surfactant protein A signaling pathways in human uterine smooth muscle cells. Biology of Reproduction. 79(2): 348-355.

Gardai SJ, Xiao YQ, Dickinson M, Nick JA, Voelker DR, Greene KE, Henson PM. 2003. By binding SIRP $\alpha$ or calreticulin/CD91, lung collectins act as dual function surveillance molecules to suppress or enhance inflammation. Cell.115(1), 13-23.

Garred P, Nielsen MA, Kurtzhals JA, Malhotra R, Madsen HO, Goka BQ, Akanmori BD, Sim RB, Hviid L. 2003. Mannose-binding lectin is a disease modifier in clinical malaria and may function as opsonin for Plasmodium falciparum-infected erythrocytes. Infection and Immunity. 71 (9):5245-5253.

George CL, Goss KL, Meyerholz DK, Lamb FS, Snyder JM. 2008. Surfactant-associated protein A provides critical immunoprotection in neonatal mice. Infection and Immunity. 76(1):380-390.

Girardi G, Yarilin D, Thurman JM, Holers VM, Salmon JE. 2006b. Complement activation induces dysregulation of angiogenic factors and causes fetal rejection and growth restriction. The journal of experimental medicine. 203 (9):2165-2175.

Gu PQ, Gao LJ, Li L, Liu Z, Luan FQ, Peng YZ, Guo XR. 2012. Endocrine disruptors, polychlorinated biphenyls-induced $\mathrm{gClqR}$-dependent apoptosis in human trophoblast cell line HTR-8/SVneo. Reproductive Sciences.19 (2): 181-189.

Hahn WH, Chang JY, Lee KS, Bae CW. 2013. Decreased expression of surfactant protein genes is associated with an increased expression of Forkhead box M1 gene in the fetal lung tissues of premature rabbits. Yonsei Medical Journal. 54(6):1422-1429.

Hakozaki Y, Yoshiba M, Sekiyama K, Seike E, Iwamoto J, Mitani K, Mine M, Morizane T, Ohtani K, Suzuki Y, Wakamiya N. 2002. Mannose-binding lectin and the prognosis of fulminant hepatic failure caused by HBV infection. Liver. 22(1):29-34.

Han YM, Romero R, Kim YM, Kim JS, Richani K, Friel LA, Kusanovic JP, Jeanty C, Vitale S, Nien JK, Espinoza J, Kim CJ. 2007. Surfactant protein-A mRNA expression by human fetal membranes is increased in histological chorioamnionitis but not in spontaneous labour at term. The Journal of Pathology. 211(4):489-496.

Hohler T, Wunschel M, Gerken G, Schneider PM, Meyer zum Buschenfelde KH, Rittner C. 1998. No association between mannose-binding lectin alleles and susceptibility to chronic hepatitis B virus infection in German patients. Experimental and Clinical Immunogenetics.15 (3): 130-133. 
Holmberg V, Onkamo P, Lahtela E, Lahermo P, Bedu-Addo G, Mockenhaupt FP, Meri S. 2012. Mutations of complement lectin pathway genes MBL2 and MASP2 associated with placental malaria. Malaria Journal. 11: 61.

Holmberg V, Schuster F, Dietz E, Sagarriga Visconti JC, Anemana SD, Bienzle U, Mockenhaupt FP. 2008. Mannose-binding lectin variant associated with severe malaria in young African children. Microbes and Infection. 10 (4): 342-348.

Janeway CA Jr, Medzhitov R. 2002. Innate immune recognition. Annual Review of Immunology. 20:197-216.

Ji X, Azumi K, Sasaki M, Nonaka M. 1997. Ancient origin of the complement lectin pathway revealed by molecular cloning of mannan binding protein-associated serine protease from a urochordate, the Japanese ascidian, Halocynthia roretzi. Proceedings of the National Academy of Sciences USA.94 (12):6340-6345. $\square$

Kannan A, Fazleabas AT, Bagchi IC, Bagchi MK. 2010. The transcription factor C/EBP $\beta$ is a marker of uterine receptivity and expressed at the implantation site in the primate. Reproductive Science. 17(5):434-443.

Karjalainen MK, Huusko JM, Tuohimaa A, Luukkonen A, Haataja R, Hallman M. 2012. A study of collectin genes in spontaneous preterm birth reveals an association with a common surfactant protein $\mathrm{D}$ gene polymorphism. Pediatric Research. 71 (1):93-99.

Katyal SL, Singh G, Locker L. 1992. Characterization of a second human pulmonary surfactant-associated protein SP-A gene. American Journal of Respiratory Cell and Molecular Biology. 6 (4): 446-452.

Kawai T, Akira S. 2010.The role of pattern-recognition receptors in innate immunity: update on Toll-like receptors. Nature Immunology. 11(5):373-384.

Kawasaki T, Etoh R, Yamashina I. 1978. Isolation and characterization of a mannan-binding protein from rabbit liver. Biochemical and Biophysical Research Communications. 81 (3): 1018-1024.

Kay S, Metkari SM, Madan T. 2015. Ovarian hormones regulate SP-D expression in the mouse uterus during estrous cycle and early pregnancy. American Journal of Reproductive Immunology. 74(1):77-88.

Kielgast S, Thiel S, Henriksen TB, Bjerke T, Olsen J, Jensenius JC. 2003. Umbilical cord mannan-binding lectin and infections in early childhood. Scandinavian Journal of Immunology. 57 (2):167-172.

Kilpatrick DC, Bevan BH, Liston WA.1995. Association between mannan binding protein deficiency and recurrent miscarriage. Human Reproduction. 10 (9):2501-2505.

Kilpatrick DC, Starrs L, Moore S, Souter V, Liston WA. 1999. Mannan binding lectin concentration and risk of miscarriage. Human Reproduction. 14(9):2379-2380.

Kilpatrick DC. 1996. Human mannan binding protein in pre-eclampsia. Immunology Letters. 49(3):175-177.

Kim CJ, Kim JS, Kim YM, Cushenberry E, Richani K, Espinoza J, Romero R. 2006. Fetal macrophages are not present in the myometrium of women with labor at term. American Journal of Obstetrics and Gynecology. 195 (3): 829-833.

Kishore U, Gaboriaud C, Waters P, Shrive AK, Greenhough TJ, Reid KBM, Sim RB, Arlaud GJ. 2004. C1q and tumor necrosis factor superfamily: modularity and versatility. Trends in Immunology. 25(10):551-561.

Kishore U, Greenhough T, Waters P, Shrive AK, Ghai R, Kamran MF, Bernal AL, Reid KB, Madan T, Chakraborty T. 2006. Surfactant proteins SP-A and SP-D: structure, function and receptors. Molecular Immunology. 43 (9):1293-1315.

Korfhagen TR, LeVine AM, Whitsett JA. 1998. Surfactant protein A (SP-A) gene targeted mice. Biochimica et Biophysica Acta. 1408 (2-3):296-302.

Kouser L, Madhukaran SP, Shastri A, Saraon A, Ferluga J, Al-Mozaini M, Kishore U. 2015. Emerging and Novel Functions of Complement Protein C1q. Frontiers in Immunology. 6:317. 
Kruse C, RosgaarA, Steffensen R, Varming K, Jensenius JC, Christiansen OB. 2002. Low serum level of mannan-binding lectin is a determinant for pregnancy outcomes in women with recurrent spontaneous abortion. American Journal of Obstetrics and Gynecology. 187 (5):1313-1320.

Kunzmann S, Wright JR, Steinhilber W, Kramer BW, Blaser K, Speer CP, Schmidt-Weber C. 2006. TGF-beta1 in SP-A preparations influence immune suppressive properties of SP-A on human CD4+ T-lymphocytes. American Journal of Physiology. Lung Cellular and Molecular Physiology. 291 (4): L747-L756.

Lahra MM, Jeffery HE. 2004. A fetal response to chorioamnionitis is associated with early survival after preterm birth. American Journal of Obstetrics and Gynecology. 190(1):147-151.

Laisk T, Peters M, Saare M, Haller-Kikkatalo K, Karro H, Salumets A. 2010. Association of CCR5, TLR2, TLR4 and MBL genetic variations with genital tract infections and tubal factor infertility. Journal of Reproductive Immunology. 87(1-2): 74-81.

Laisk T, Peters M, Salumets A. 2011. Mannose-binding lectin genotypes: potential role in tubal damage and adverse IVF outcome. Journal of Reproductive Immunology. 92(1-2):62-67.

Lee DC, Romero R, Kim CJ, Chaiworapongsa T, Tarca AL, Lee J, Suh YL, Mazaki-Tovi S, Vaisbuch E, Mittal P, Draghici S, Erez O, Kusanovic JP, Hassan SS, Kim JS. 2010. Surfactant protein-A as an anti-inflammatory component in the amnion: implications for human pregnancy. The Journal of Immunology. 184(11):6479-1691.

Leth-Larsen R, Floridon C, Nielsen O, Holmskov U. 2004.Surfactant protein D in the female genital tract. Molecular Human Reproduction. 10(3):149-154.

Lokki AI, Heikkinen-Eloranta J, Jarva H, Saisto T, Lokki ML, Laivuori H, Meri S. 2014. Complement activation and regulation in preeclamptic placenta. Frontiers in Immunology. 5:312.

MacNeill C, Umstead TM, Phelps DS, Lin Z, Floros J, Shearer DA, Weisz J. 2004. Surfactant protein A, an innate immune factor, is expressed in the vaginal mucosa and is present in vaginal lavage fluid. Immunology. 111(1): 91-99.

Madhukaran SP, Kishore U, Jamil K, Choolani M, Lu J. 2015a. Decidual expression and localization of human surfactant protein SP-A and SP-D, and complement protein C1q. Molecular Immunology. 66(2):197-207.

Madhukaran SP, Kishore U, Jamil K, Teo BH, Choolani M, Lu J.2015b.Transcriptional Factor PU.1 Regulates Decidual C1q Expression in Early Pregnancy in Human. Frontiers in Immunology. 6:53.

Madhukaran SP, Koippallil Gopalakrishnan AR, Pandit H, Marri ED, Kouser L, Jamil K, Alhamlan FS, Kishore U, Madan T. 2015c. Expression of surfactant proteins SP-A and SP-D in murine decidua and immunomodulatory effects on decidual macrophages. Immunobiology. 221 (2):377-386.

Madsen HO, Garred P, Kurthals JA, Lamm LU, Ryder LP, Thiel S, Svejgaard A. 1994. A new frequent allele is the missing link in the structural polymorphism of the human mannan-binding protein. Immunogenetics. 40(1): $37-44$.

Madsen HO, Garred P, Thiel S, Kurthals JA, Lamm LU, Ryder LP, Svejgaard A. 1995. Interplay between promoter and structural gene variants control basal serum level of mannan-binding protein. The Journal of Immunology. 155 (6):3013-3020.

Madsen HO, Satz ML, Hogh B, Svejgaard A, Garred P. 1998. Different molecular events result in low protein levels of mannan-binding lectin in populations from Southeast Africa and South America. The Journal of Immunology. 161 (6):3169-3175.

Madsen J, Kliem A, Tornoe I, Skjodt K, Koch C, Holmskov U. 2000. Localization of lung surfactant protein D on mucosal surfaces in human tissues. The Journal of Immunology.164 (11): 5866-5870. 
Madsen J, Tornoe I, Nielsen O, Koch C, Steinhilber W, Holmskov U. 2003. Expression and localization of lung surfactant protein A in human tissues. American Journal of Respiratory Cell and Molecular Biology. 29 (5): 591-597.

Malhotra R, Willis AC, Lopez Bernal A, Thiel S, Sim RB. 1994. Mannan-binding protein levels in human amniotic fluid during gestation and its interaction with collectin receptor from amnion cells. Immunology. 82(3):439-444.

Malhotra R, Wormald MR, Rudd PM, Fischer PB, Dwek RA, Sim RB. 1995. Glycosylation changes of IgG associated with rheumatoid arthritis can activate complement via the mannose-binding protein. Nature Medicine.1(3):237-243.

Masat E, Bossi F, Agostinis C, Tonon M, Radillo O, De Seta F, Bulla R. 2012. C1q is responsible of the anti-inflammatory behavior of decidual endothelial cells. Journal of reproductive immunology. 94 (1): 91 . DOI: http://dx.doi.org/10.1016/j.jri.2012.03.409.

Matsushita, M, Ezekowitz RA, Fujita T. 1995. The Gly-543-->Asp allelic form of human mannose-binding protein (MBP) fails to bind MBP-associated serine protease. Biochemical Journal. 311 (Pt3):1021-1023.

McCormick SM, Boggaram V, Mendelson CR. 1994. Characterization of mRNA transcripts and organization of human surfactant protein SP-A1 and SP-A2 genes. American Journal of Physiology. 266 (4 Pt. 1): L354-L366.

Medzhitov R. 2007. Recognition of microorganisms and activation of the immune response. Nature. 449(7164):819-826.

Megia A, Gallart L, Fernández-Real JM, Vendrell J, Simón I, Gutierrez C, Richart C. 2004. Mannose-binding lectin gene polymorphisms are associated with gestational diabetes mellitus. The Journal of Clinical Endocrinology and Metabolism. 89(10), 5081-5087.

Mendelson CR, Condon JC. 2005. New insights into the molecular endocrinology of parturition. The Journal of Steroid Biochemistry and Molecular Biology. 93(2-5):113-119.

Miyamura K, Malhotra R, Hoppe HJ, Reid KB, Phizackerley PJ, Macpherson P, López Bernal A.1994. Surfactant proteins A (SP-A) and D (SP-D): levels in human amniotic fluid and localization in the fetal membranes. Biochimica et Biophysica Acta. 1210(3):303-307.

Molina MC, Ferreira V, Valck C, Aguilar L, Orellana J, Rojas A, Ramirez G, Billetta R, Schwaeble W, Lemus D, Ferreira A. 2005. An in vivo role for Trypanosoma cruzi calreticulin in antiangiogenesis. Molecular and Biochemical Parasitology. 140 (2): 133-140.

Montalbano AP, Hawgood S, Mendelson CR. 2013. Mice deficient in surfactant protein A (SP-A) and SP-D or in TLR2 manifest delayed parturition and decreased expression of inflammatory and contractile genes. Endocrinology. 154 (1):483-498.

Morris KM, Colten HR, Bing DH. 1978. The first component of complement. A quantitative comparison of its biosynthesis in culture by human epithelial and mesenchymal cells. The Journal of Experimental Medicine. 148 (4) 1007-1019.

Myatt L, Sun K. 2010. Role of fetal membranes in signaling of fetal maturation and parturition. The International Journal of Developmental Biology. 54(2-3):545-553.

Nauta AJ, Castellano G, Xu W, Woltman AM, Borrias MC, Daha MR, van Kooten C, Roos A. 2004. Opsonization with $\mathrm{C} 1 \mathrm{q}$ and mannose-binding lectin targets apoptotic cells to dendritic cells. The Journal of Immunology. 173 (5):3044-3050.

Nowicki S, Martens MG, Nowicki BJ. 1995. Gonococcal infection in a nonhuman host is determined by human complement C1q. Infection and Immunity.63(12):4790-4794. 
Oberley RE, Goss KL, Ault KA, Crouch EC, Snyder JM. 2004. Surfactant protein D is present in the human female reproductive tract and inhibits Chlamydia trachomatis infection. Molecular Human Reproduction. 10(12):861-870.

Oberley RE, Goss KL, Hoffmann DS, Ault KA, Neff TL, Ramsey KH, Snyder JM. 2007. Regulation of surfactant protein $\mathrm{D}$ in the mouse female reproductive tract in vivo. Molecular Human Reproduction.13(12):863-868.

Oger P, Bulla R, Tedesco F, Portier A, Dubanchet S, Bailly M, Wainer R, Chaouat G, Lédée N. 2009. Higher interleukin-18 and mannose-binding lectin are present in uterine lumen of patients with unexplained infertility. Reproductive Biomedicine Online. 19(4):591-598.

Oudshoorn AM, van den Dungen FA, Bach KP, Koomen I, Fetter WP, Catsburg A, Savelkoul PH, van Elburg RM. 2008. Mannose-binding lectin in term newborns and their mothers: genotypic and phenotypic relationship. Human Immunology. 69(6):344-348.

Paavonen J, Eggert-Kruse W.1999. Chlamydia trachomatis: impact on human reproduction. Human Reproduction Update. 5(5):433-447.

Païdassi H, Tacnet-Delorme P, Garlatti V, Darnault C, Ghebrehiwet B, Gaboriaud C, Arlaud GJ, Frachet P. 2008. C1q binds phosphatidylserine and likely acts as a multiligand-bridging molecule in apoptotic cell recognition. The Journal of Immunology. 180(4):2329-2338.

Persson A, Rust K, Chang D, Moxley M, Longmore W, Crouch E. 1988. CP4: a pneumocyte-derived collagenous surfactant-associated protein. Evidence for heterogeneity of collagenous surfactant proteins. Biochemistry. 27(23):8576-8584.

Pertyńska M, Tchórzewski H, Cedzyński M, Lewkowicz P, Sobczak M, Cypryk K, Wilczyński J. 2001. Levels of mannose binding lectin in early pregnancy complicated by diabetes mellitus type 1--preliminary report. Ginekologia Polska. 72(12A):1267-1271.

Pertyńska Marczewska M, Cedzyński M, Świerzko A, Szala A, Sobczak M, Cypryk K, Wilczyński J. 2009. Evaluation of lectin pathway activity and mannan-binding lectin levels in the course of pregnancy complicated by diabetes type 1, based on the genetic background. Archivum Immunologiae Et Therapia Experimentalis. 57(3), 221-228.

Petitbarat M, Durigutto P, Macor P, Bulla R, Palmioli A, Bernardi A, De Simoni MG, Ledee N, Chaouat G, Tedesco F. 2015. Critical Role and Therapeutic Control of the Lectin Pathway of Complement Activation in an Abortion-Prone Mouse Mating. The Journal of Immunology. 195 (12):5602-5607.

Pop VJ, de Vries E, van Baar AL, Waelkens JJ, de Rooy HA, Horsten M, Donkers MM, Komproe IH, van Son MM, Vader HL.1995. Maternal thyroid peroxidase antibodies during pregnancy: a marker of impaired child development? The Journal of Clinical Endocrinology \& Metabolism. 80(12):3561-3566.

Potlukova E, Freiberger T, Limanova Z, Jiskra J, Telicka Z, Bartakova, J,Springer D, Vitkova H, Trendelenburg M. 2013. Association between low levels of Mannan-binding lectin and markers of autoimmune thyroid disease in Pregnancy. PLoS ONE. 8(12): e81755.

Ramos R, Juri M, Ramos A, Hoecker G, Lavandero S, Pena P, Morella A, Repetto Y, Aguillion JC, Ferrerira A. 1991. An immunogenetically defined and immunodominant Trypanosoma cruzi antigen. The American Journal of Tropical Medicine and Hygiene. 44(3): 314-322.

Richani K, Soto E, Romero R, Espinoza J, Chaiworapongsa T, Nien JK, Edwin S, Kim YM, Hong JS, Mazor M. 2005. Normal pregnancy is characterized by systemic activation of the complement system. Journal of Maternal-Fetal and Neonatal Medicine. 17(4):239-245.

Romero R, Hassan SS, Gajer P, Tarca AL, Fadrosh DW, Nikita L, Galuppi M, Lamont RF, Chaemsaithong P, Miranda J, Chaiworapongsa T, Ravel J. 2014. The composition and stability of the vaginal microbiota of normal pregnant women is different from that of non-pregnant women. Microbiome. 2(1):4. 
Roos A, Bouwman LH, Munoz J, Zuiverloon T, Faber-Krol MC, Fallaux-van den Houten FC, Klar-Mohamad N, Hack CE, Tilanus MG, Daha MR. 2003. Functional characterization of the lectin pathway of complement in human serum. Molecular Immunology. 39(11):655-668.

Saitoh S, Nakanishi A, Ichijo M. 1983. Immune complex and complement levels in spontaneous abortions and normal pregnancy. Nihon Sanka Fujinka Gakkai Zasshi. 35(11):1981-1990.

Salminen A, Paananen R, Vuolteenaho R, Metsola J, Ojaniemi M, Autio-Harmainen H, Hallman M. 2008. Maternal endotoxin-induced preterm birth in mice: fetal responses in toll-like receptors, collectins, and cytokines. Pediatric Research. 63(3):280-286.

Salminen A, Vuolteenaho R, Paananen R, Ojaniemi M, Hallman M. 2011. Surfactant protein A modulates the lipopolysaccharide-induced inflammatory response related to preterm birth. Cytokine. 56(2): 442-449.

Salminen A, Vuolteenaho R, Paananen R, Ojaniemi M, Hallman M. 2012. Surfactant protein D modulates levels of IL-10 and TNF- $\alpha$ in intrauterine compartments during lipopolysaccharide-induced preterm birth.Cytokine. 60(2): 423-430.

Sati L, Seval-Celik Y, Demir R. 2010. Lung surfactant proteins in the early human placenta. Histochemistry and Cell Biology. 133(1):85-93.

Sellar GC, Cockburn D, Reid KB. 1992. Localization of the gene cluster encoding the A, B, and C chains of human C1q to 1p34.1-1p36.3. Immunogenetics. 35(3):214-216.

Shippey SH $3^{\text {rd }}$, Zahn CM, Cisar MM, Wu TJ, Satin AJ. 2005. Use of the placental perfusion model to evaluate transplacental passage of Trypanosoma cruzi. American Journal of Obstetrics and Gynecology. 192(2): 586591.

Silver KL, Higgins SJ, McDonald CR, Kain KC. 2010. Complement driven innate immune response to malaria: fuelling severe malarial diseases. Cellular Microbiology. 12 (8):1036-1045.

Singh J, Ahmed A, Girardi G. 2011. Role of complement component C1q in the onset of preeclampsia in mice. Hypertension.58 (4): 716-724.

Sinha D, Wells M, Faulk WP. 1984. Immunological studies of human placentae: complement components in pre-eclamptic chorionic villi. Clinical \& Experimental Immunology. 56(1):175-184.

Smallridge RC. 2000. Postpartum thyroid disease. A model of immunologic dysfunction. Clininal and Applied Immunology Reviews. 1:89-103.

Snegovskikh VV, Bhandari V, Wright JR, Tadesse S, Morgan T, Macneill C, Foyouzi N, Park JS, Wang Y, Norwitz ER. 2011. Surfactant protein-A (SP-A) selectively inhibits prostaglandin F2 $\alpha$ (PGF2alpha) production in term decidua: implications for the onset of labor. The Journal of Clinical Endocrinology and Metabolism. 96(4):E624-632.

Sotiriadis G, Dodagatta-Marri E, Kouser L, Alhamlan FS, Kishore U, Karteris E. 2015. Surfactant Proteins SPA and SP-D Modulate Uterine Contractile Events in ULTR Myometrial Cell Line. PLoS one.10(12):e0143379.

Stagnaro-Green A, Abalovich M, Alexander E, Azizi F, Mestman J, Negro R, et al. 2011. Guidelines of the American Thyroid Association for the diagnosis and management of thyroid disease during pregnancy and postpartum. Thyroid. 21 (10):1081-1125.

Storelli MM, Barone G, Storelli A, Marcotrigiano GO. 2011. Levels and congener profiles of PCBs and PCDD/Fs in blue shark (Prionace glauca) liver from the South-Eastern Mediterranean Sea (Italy). Chemosphere. 82(1):37-42.

Szala A, Paradowska E, Nowakowska D, Swierzko AS, Dzierzanowska-Fangrat K, Sokolowska A,Studzinska M, Gaj Z, Suski P, Kasztelewicz B, Wilczynski J, Cedzynski M. 2011. Mannan-binding lectin-2 (MBL2) gene polymorphisms in prenatal and perinatal cytomegalovirus infections. Molecular Immunology. 48(15-16):22032206. 
Sziller I, Babula O, Hupuczi P, Nagy B, Rigó B, Szabó G, Papp Z, Linhares IM, Witkin SS. 2007a. Mannosebinding lectin (MBL) codon 54 gene polymorphism protects against development of preeclampsia, HELLP syndrome and pre-eclampsia-associated intrauterine growth restriction. Molecular Human Reproduction. 13(4):281-285.

Sziller I, Babula O, Ujhazy A, Nagy B, Hupuczi P, Papp Z, Linhares IM, Ledger WJ, Witkin SS. $2007 \mathrm{~b}$. Chlamydia trachomatis infection, Fallopian tube damage and a mannose-binding lectin codon 54 gene polymorphism. Human Reproduction. 22(7): 1861-1865.

Tamblyn JA, Lissauer DM, Powell R, Cox P, Kilby MD. 2013.The immunological basis of villitis of unknown etiology - review. Placenta. 34(10): 846-55.

Tannetta D, Mackeen M, Kessler B, Sargent I, Redman C. 2012. Multi-dimensional protein identification technology analysis of syncytiotrophoblast vesicles released from perfused preeclampsia placentas. Pregnancy Hypertension. 2(3):201-202.

Terai I, Kobayashi K, Matsushita M, Miyakawa H, Mafune N, Kikuta H. 2003. Relationship between gene polymorphisms of mannose-binding lectin (MBL) and two molecular forms of MBL. European Journal of Immunology. 33 (10):2755-2763.

Than NG, Romero R, Erez O, Kusanovic, JP, Tarca, AL, Edwin SS, et al. (2008). A Role for Mannose-binding lectin, a component of the innate immune system in pre-eclampsia. American Journal of Reproductive Immunology. 60(4): 333-345.

Thevenon AD, Leke RG, Suguitan AL, Zhou JA, Taylor DW. 2009. Genetic polymorphisms of mannosebinding lectin do not influence placental malaria but are associated with preterm deliveries. Infection and Immunity. 77(4): 1483-1491.

Thiel S. 2007. Complement activating soluble pattern recognition molecules with collagen-like regions, mannan-binding lectin, ficolins and associated proteins. Molecular Immunology. 44(16):3875-3888.

Thiel S, Kolev M, Degn S, Steffensen R, Hansen AG, Ruseva M, Jensenius JC. 2009. Polymorphisms in mannan-binding lectin (MBL)-associated serine protease 2 affect stability, binding to MBL, and enzymatic activity. The Journal of Immunology. 182(5):2939-2947.

Thiel S, Vorup-Jensen T, Stover CM, Schwaeble W, Laursen SB, Poulsen K, Willis AC, Eggleton P, Hansen S, Holmskov U, Reid KB, Jensenius JC. 1997. A second serine protease associated with mannan-binding lectin that activates complement. Nature. 386 (6624): 506-510.

Thio CL, Mosbruger T, Astemborski J, Greer S, Kirk GD, O’Brien SJ, Thomas DL. 2005. Mannose binding lectin genotypes influence recovery from hepatitis B virus infection. Journal of Virology. 79(14):9192-9196.

Uemura K, Saka M, Nakagawa T, Kawasaki N, Thiel S, Jensenius JC, Kawasaki T. 2002. L-MBP is expressed in epithelial cells of mouse small intestine. The Journal of Immunology. 169(12):6945-6950.

Underwood MA, Gilbert WM, Sherman MP. 2005.Amniotic fluid: not just fetal urine anymore. Journal of Perinatology. 25(5):341-348.

van de Geijn FE, de Man YA, Wuhrer M, Willemsen SP, Deelder AM, Hazes JM, Dolhain RJ. 2011. Mannosebinding lectin does not explain the course and outcome of pregnancy in rheumatoid arthritis. Arthritis Research \& Therapy. 13(1):R10.

van de Geijn FE, Dolhain RJ, van Rijs W, Hazes JM, de Groot CJ. 2007b. Mannose-binding lectin genotypes and pre-eclampsia: a case-control study. Human Immunology. 68(11):888-893.

van de Geijn FE, Dolhain RJ, van Rijs W, Willemsen SP, Hazes JM, de Groot CJ. 2008.Mannose-binding lectin genotypes are associated with shorter gestational age. An evolutionary advantage of low MBL production genotypes? Molecular Immunology. 45(5):1514-1518. 
van de Geijn FE, Roos A, de Man YA, Laman JD, de Groot CJ, Daha MR, Hazes JM, Dolhain RJ. 2007a. Mannose-binding lectin levels during pregnancy: a longitudinal study. Human Reproduction. 22 (2):362-371.

van de Geijn FE, Wuhrer M, Selman MH, Willemsen SP, de Man YA, $\square$ Deelder AM, Hazes JM, Dolhain RJ. 2009. Immunoglobulin G galactosylation and sialylation are associated with pregnancy-induced improvement of rheumatoid arthritis and the postpartum flare: results from a large prospective cohort study. Arthritis Research \& Therapy.11(6):R193.

Vegh Z, Goyarts EC, Rozengarten K, Mazumder A, and Ghebrehiwet B. 2003. Maturation-dependent expression of $\mathrm{C} 1 \mathrm{q}$ binding proteins on the cell surface of monocyte-derived dendritic cells. International Immunopharmacology. 3 (3):345-357.

Vianna P, Da Silva GK, Dos Santos BP, Bauer ME, Dalmáz CA, Bandinelli E, Chies JA. 2010.Association between mannose-binding lectin gene polymorphisms and pre-eclampsia in Brazilian women. American Journal of Reproductive Immunology.64(5):359-74.

Voss T, Eistetter H, Schäfer KP, Engel J. 1988. Macromolecular organization of natural and recombinant lung surfactant protein SP 28-36. Structural homology with the complement factor C1q. Journal of Molecular Biology. 201(1):219-227.

Wagner S, Lynch NJ, Walter W, Schwaeble WJ, Loos M. 2003. Differential expression of the murine mannosebinding lectins $\mathrm{A}$ and $\mathrm{C}$ in lymphoid and non-lymphoid organs and tissues. The Journal of Immunology.170(3):1462-1465.

Wahab Mohamed WA, Saeed MA. 2012. Mannose-binding lectin serum levels in neonatal sepsis and septic shock. The Journal of Maternal-Fetal \& Neonatal Medicine. 25(4):411-414.

Wu Y, Zhou Q, Wang H, Tian T, Zhu Q, Wang H, Bai X, Yang X, Wang Z, Dong M. 2013. Potential role of mannose-binding lectin in intrauterine transmission of hepatitis B virus. Japanese Journal of Infectious Diseases. 66(5), 391-393.

Yadav AK, Chaudhari H, Shah PK, Madan T. 2016. Expression and localization of collectins in feto-maternal tissues of human first trimester spontaneous abortion and abortion prone mouse model. Immunobiology. 221(2):260-268.

Yadav AK, Chaudhari H, Warke H, Shah PK, Dodagatta-Marri E, Kishore U, Madan T. 2014. Differential expression of collectins in human placenta and role in inflammation during spontaneous labor. PLoS One. 9(10):e108815.

Zhang TC, Liu W, Liu XQ, Pan FM, Gao YF, Yan F, Li X. 2013. Single nucleotide polymorphisms rs2120131, rs4935047, and rs7095891 in the MBL2 gene show no association with susceptibility to chronic hepatitis B in a Chinese Han population. Journal of Medical Virology. 85(4):602-607. 
Figure 1: Participation of SP-A, SP-D, MBL and C1q in pregnancy. Processes denoted in black are reported, processes denoted with red asterisks $(*)$ are specific functions of SP-A and C1q while this has not been seen with SP-D and MBL, and processes denoted in red are not yet known but possible functional properties of soluble defense collagens being expressed during pregnancy.

Figure 2: Expression of collectins and C1q in non-pregnant uterus

Figure 3: Expression of collectins and C1q in pregnant uterus

Figure 4: Immunofluorescent triple staining of CK-7, PU.1 and C1q in early human decidua. Decidual cells were fixed and permeabilized before incubating with primary and secondary antibodies against CK-7, PU.1, C1q or their corresponding control isotype. (A)-(C) Image of three different decidual samples showing the immunolocalization of CK-7 (AMCA, blue channel), PU.1 (cy3, red channel), and C1q (FITC, green channel), and composite (merge). (D) Isotype matched controls.

Figure 5: Expression of SP-A1, SP-A2, SP-D, C1qA, C1qB, C1qC in human decidua. Human decidual samples were collected from healthy women undergoing elective termination of pregnancy or during labor. Informed and written consent for research participation was obtained from each patient through procedures approved by National University Health System and National University of Singapore's Domain Specific Review Boards. Results are representative of two independent experiment performed in triplicate. Values are shown as mean \pm standard error of the mean.

(A) Expression of SP-A1, SP-A2, SP-D, C1q A, C1q B, and C1q C in human decidua obtained from women undergoing elective termination of pregnancy during first trimester. 7+6: 7 weeks and 6 days of gestation; 8+2 : Average of 5 samples of 8 weeks and 2 days of gestation; 8+6: 8 weeks and 6 days of gestation; 9+0: Average of 2 samples of 9 weeks of gestation; $9+2$ : 9 weeks and 2 days of gestation; $9+5$ : 9 weeks and 5 days of gestation; $10+3$ : 10 weeks and 3 days of gestation.

(B) Expression of SP-A1, SP-A2, SP-D, C1q A, C1q B, and C1q C in human decidua obtained from women undergoing elective termination of pregnancy during first trimester and from women undergoing labor with a previous history of miscarriages. $8+4$ ( 8 weeks and 4 days of gestation) with 1 previous miscarriage, $9+4$ (9 weeks and 4 days of gestation) with RPL with 4 previous miscarriages; 39+1 (39 weeks and 1 day of gestation) had RPL with 2 previous miscarriages; Caesarean section (CS) with 2 previous miscarriages; lower segment caesarean section (LSCS) with 2 previous miscarriages.

Figure 6: Animal studies showing the anti-inflammatory (protective) and pro-inflammatory (detrimental) role of SP-A in pregnancy and parturition.

Figure 7: Role of MBL-2 gene polymorphism in preeclampsia via complement system. 
Table 1: Gene organization and function of SP-A, SP-D, MBL and C1q

\begin{tabular}{|c|c|c|c|c|c|}
\hline Gene & Chromosome & $\begin{array}{c}\text { Mol. } \\
\text { Weight } \\
\text { (kDa) }\end{array}$ & $\begin{array}{c}\text { Gly-X-Y } \\
\text { repeats }\end{array}$ & $\begin{array}{c}\text { Primary } \\
\text { Source }\end{array}$ & $\begin{array}{c}\text { Complement } \\
\text { activation }\end{array}$ \\
\hline SFTPA & $10 \mathrm{q} 21-\mathrm{q} 24$ & $26-35$ & $23^{*}$ & Lungs & No \\
\hline SFTPD & $10 \mathrm{q} 23-\mathrm{q} 23$ & 43 & 59 & Lungs & No \\
\hline MBL & $10 \mathrm{q} 11.2-\mathrm{q} 21$ & $28-32$ & $19^{*}$ & Liver & Yes \\
\hline C1q & $1 \mathrm{p} 34.1-1 \mathrm{p} 36.3$ & $32-40$ & $23^{*}$ & Liver & Yes \\
\hline
\end{tabular}

* Interrupted triplets by kink (no.). SP-A : GEMPCPP (13); MBL: GGTGQ (8); C1q A:GIRT (10); C1q C: GIPAIK (11).

Table 2: Tissue distribution of SP-A, SP-D, MBL and C1q in gestational and non-gestational tissues

\begin{tabular}{|l|l|l|}
\hline Proteins & Non gestational tissues & Gestational tissues \\
\hline SP-A & $\begin{array}{l}\text { Lungs: alveolar type II cells, Clara } \\
\text { cells, trachea, mesothelial tissues, } \\
\text { synovial cells, gastrointestinal tract, } \\
\text { pancreas, thymus, small intestine, } \\
\text { colon, peritoneal wall, bile }\end{array}$ & $\begin{array}{l}\text { Amniotic fluid, amniotic epithelial cells, } \\
\text { vaginal epithelium, vaginal lavage, uterus, } \\
\text { ovary, amnion, chorion, fetal membrane, } \\
\text { decidua, decidual stromal cells, trophoblast, } \\
\text { placenta, placental villi, }\end{array}$ \\
\hline SP-D & $\begin{array}{l}\text { Lungs: alveolar type II cells, Clara } \\
\text { cells, trachea, mesothelial tissues, } \\
\text { synovial cells, gastrointestinal tract, } \\
\text { pancreas, small intestine, brain, } \\
\text { salivary gland, heart, kidney }\end{array}$ & $\begin{array}{l}\text { Amniotic fluid, amniotic epithelial cells, } \\
\text { vagina, uterus, ovary, oviduct, fallopian tube, } \\
\text { endometrium, fetal membrane, placenta, } \\
\text { decidua, trophoblast, decidual stromal cells, } \\
\text { placental villi, }\end{array}$ \\
\hline MBL & $\begin{array}{l}\text { Liver: hepatocytes, monocyte-derived } \\
\text { dendritic cells; Kidney, Small } \\
\text { intestine: epithelial cells, lymphoid and } \\
\text { non- lymphoid organs and tissues }\end{array}$ & Amniotic fluid, vaginal epithelial cells \\
\hline C1q & $\begin{array}{l}\text { Liver, monocytes, macrophages, } \\
\text { epithelial cells, mesenchymal cells, } \\
\text { dendritic cells, microglial cells, } \\
\text { fibroblasts. }\end{array}$ & $\begin{array}{l}\text { Placenta, Fetal vessels, spiral arteries, } \\
\text { trophoblasts, decidual stromal cells, decidual } \\
\text { endothelial cells }\end{array}$ \\
\hline
\end{tabular}

Table 3: Levels of SP-A, SP-D, MBL and C1q in amniotic fluid during mid and term pregnancy

\begin{tabular}{|l|l|l|}
\hline \multirow{2}{*}{ Proteins } & Amniotic fluid & \\
\cline { 2 - 3 } & Mid pregnancy & Term pregnancy \\
\hline SP-A & Not expressed & $30-31^{\text {st }}$ week: $3 \mu \mathrm{g} / \mathrm{ml}$ \\
& & $40-41^{\text {st }}$ week: $24 \mu \mathrm{g} / \mathrm{ml}$ \\
& & $39^{\text {th }}$ week $: 4978 \mu \mathrm{g} / \mathrm{ml}$ \\
& & Term no labor $: 2.2-15 \mu \mathrm{g} / \mathrm{ml}$ \\
& & Term with labor: $1.2-10 \mu \mathrm{g} / \mathrm{ml}$ \\
\hline SP-D & $14-16^{\text {th }}$ week: $0.11 \mu \mathrm{g} / \mathrm{ml}$ & $38^{\text {th }}$ and $42^{\text {nd }}$ week: $26.3 \mu \mathrm{g} / \mathrm{ml}$ \\
& & $39^{\text {th }}$ week: $793 \mu \mathrm{g} / \mathrm{ml}$ \\
\hline MBL & Not known & Before $35^{\text {th }}$ week: $304 \mu \mathrm{g} / \mathrm{ml}$ \\
& & After $35^{\text {th }}$ week: $1070 \mu \mathrm{g} / \mathrm{ml}$ \\
\hline C1q & Not known & Less than $0.5 \mu \mathrm{g} / \mathrm{ml}$ \\
\hline
\end{tabular}




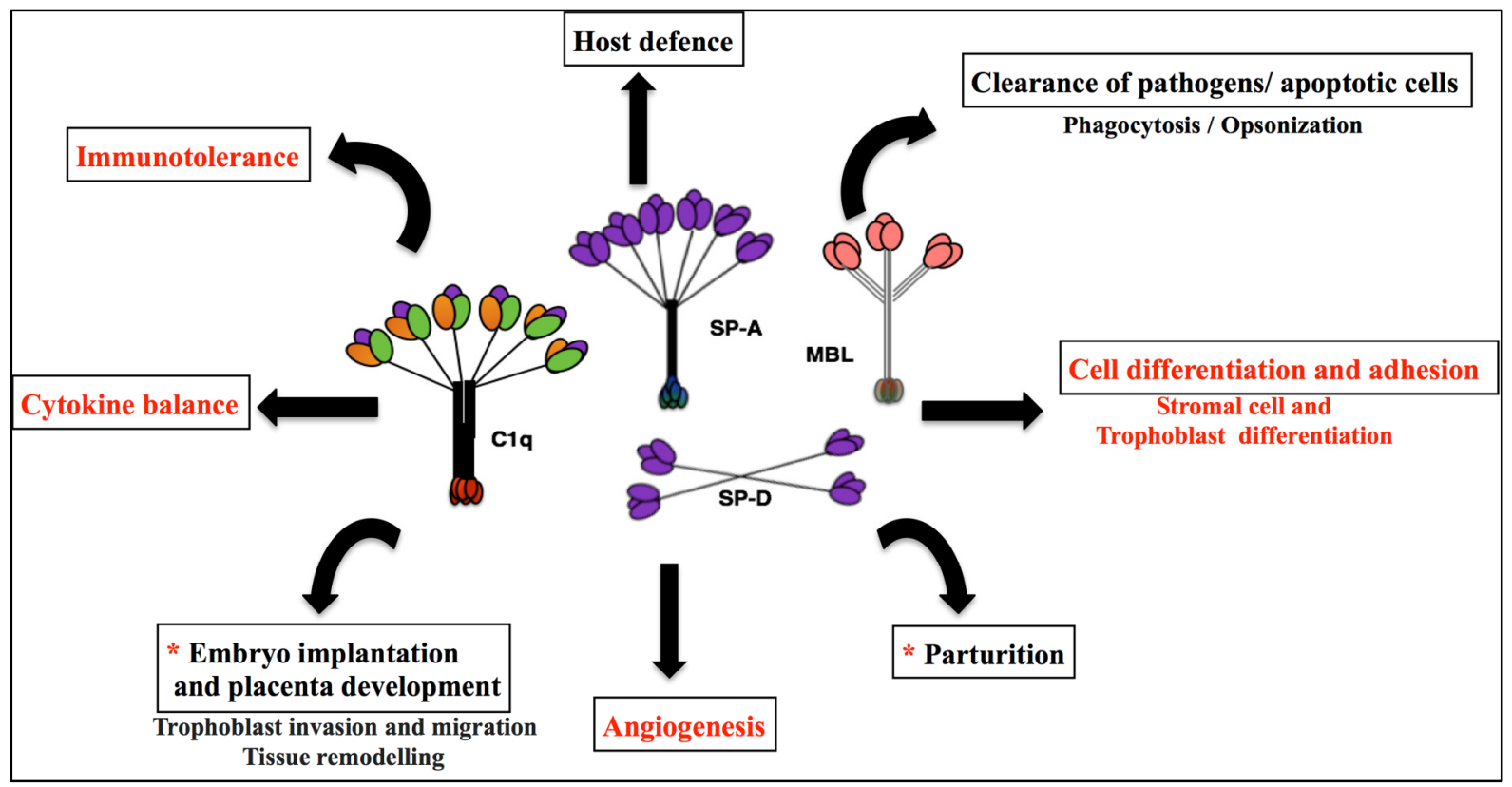

Figure 1: Madhukaran et al 


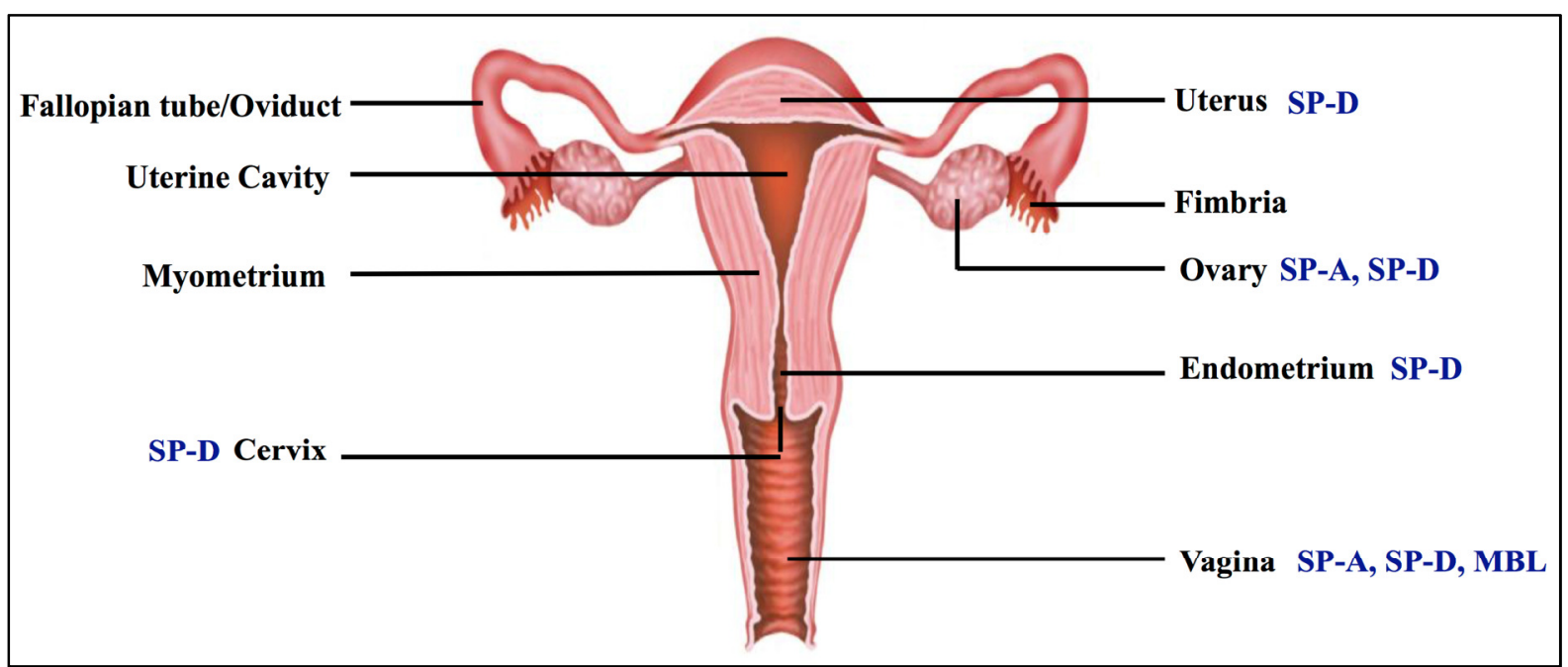

Figure 2: Madhukaran et al 


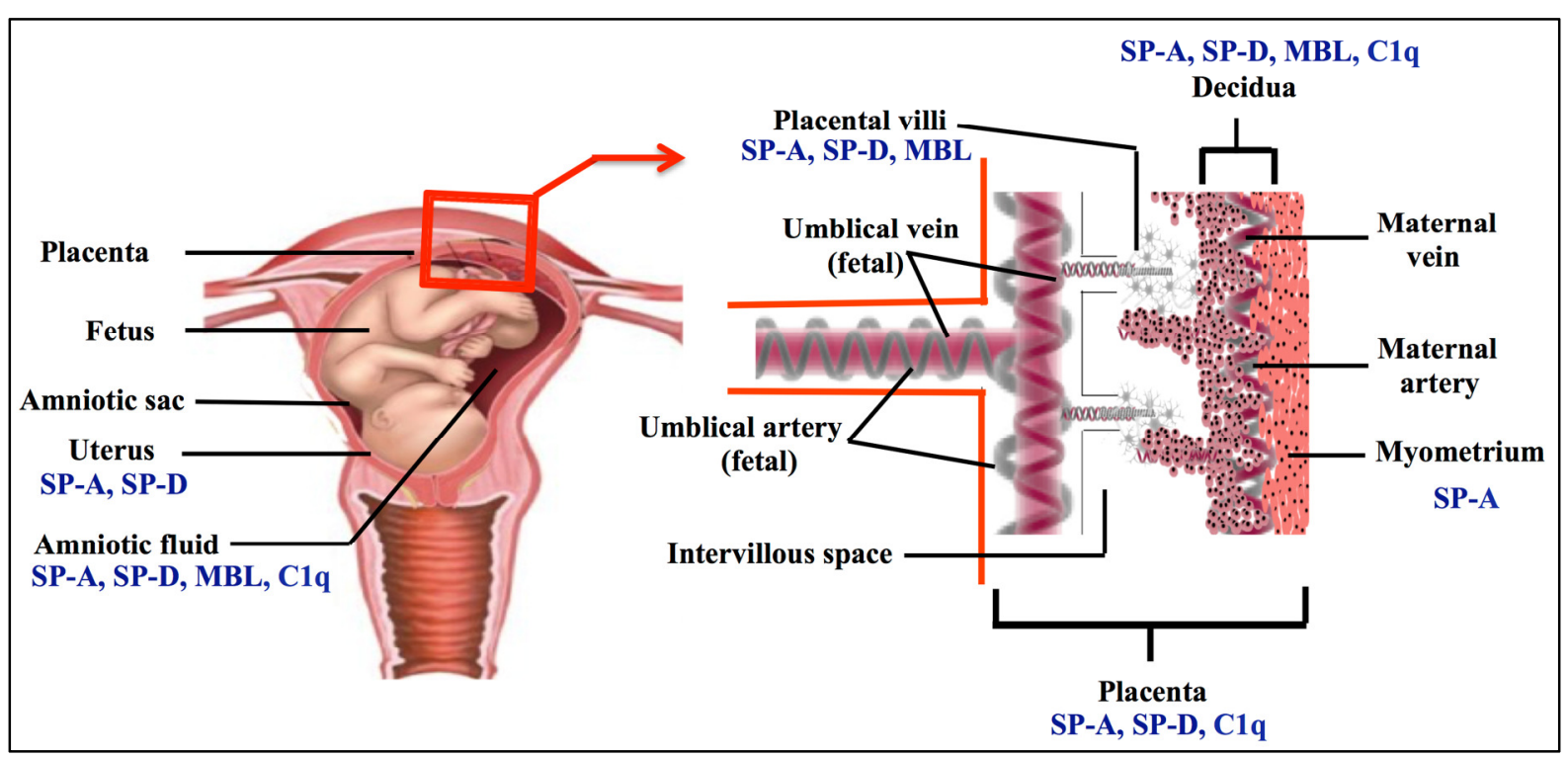

Figure 3: Madhukaran et al 


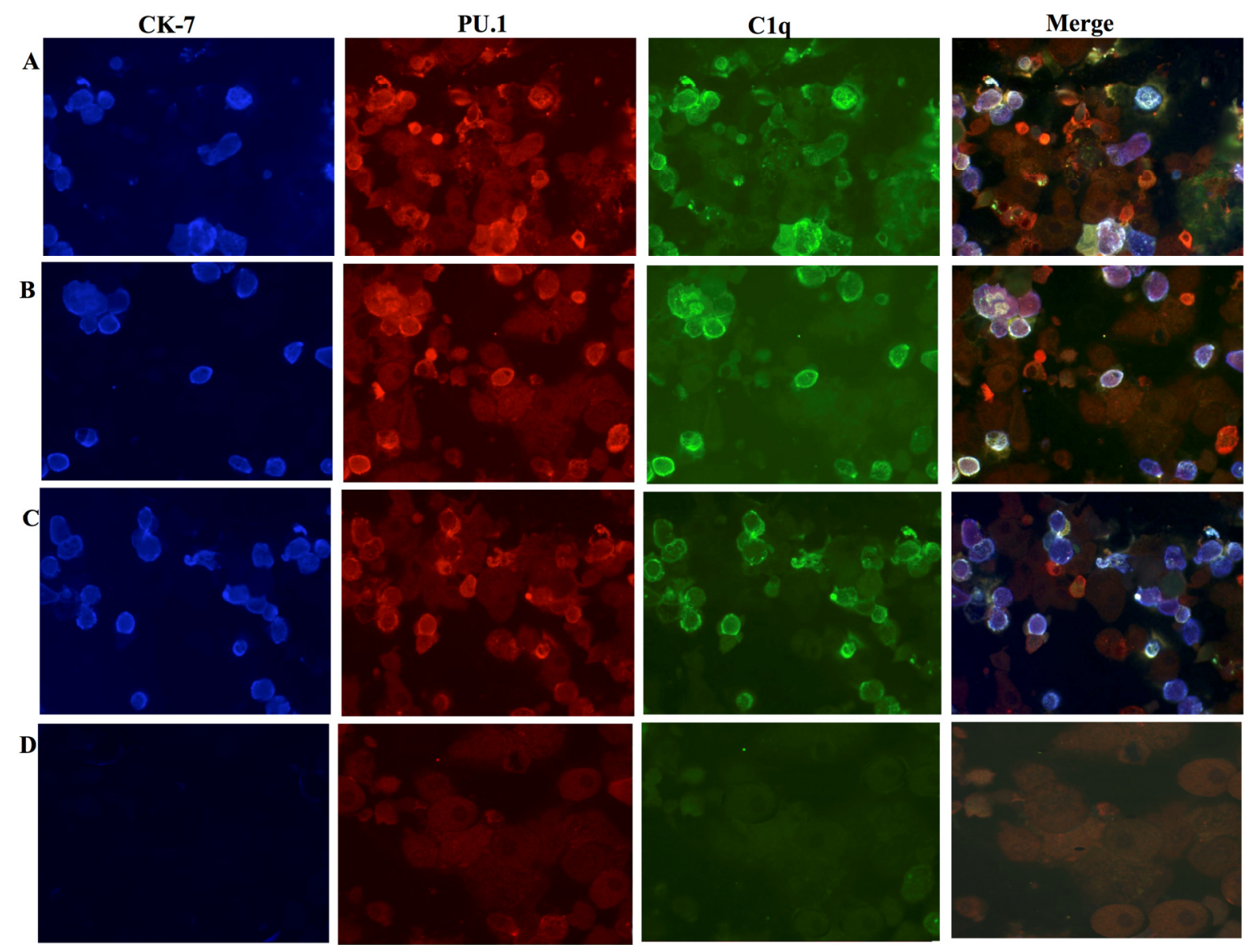

Figure 4: Madhukaran et al 


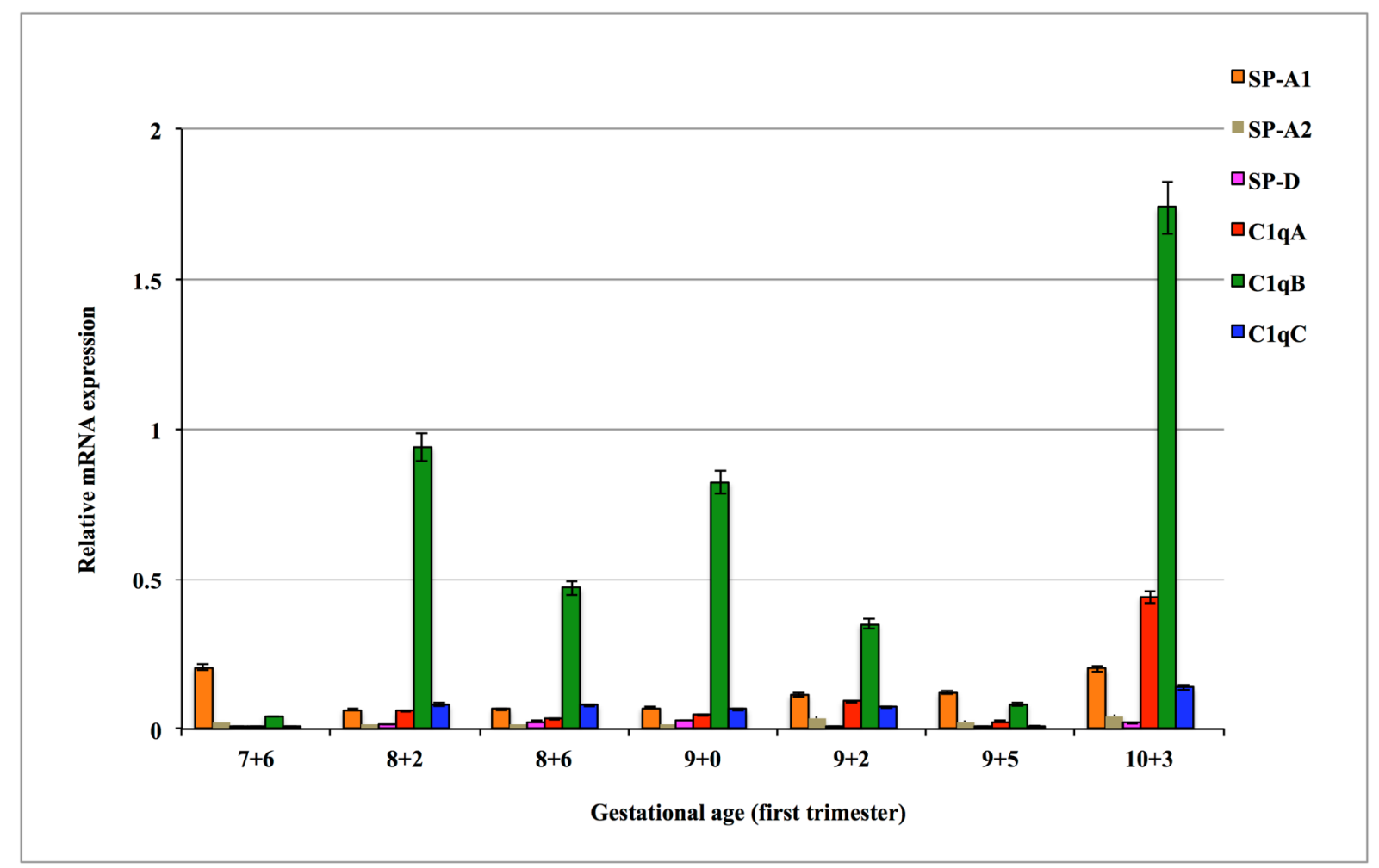

Figure 5A: Madhukaran et al 


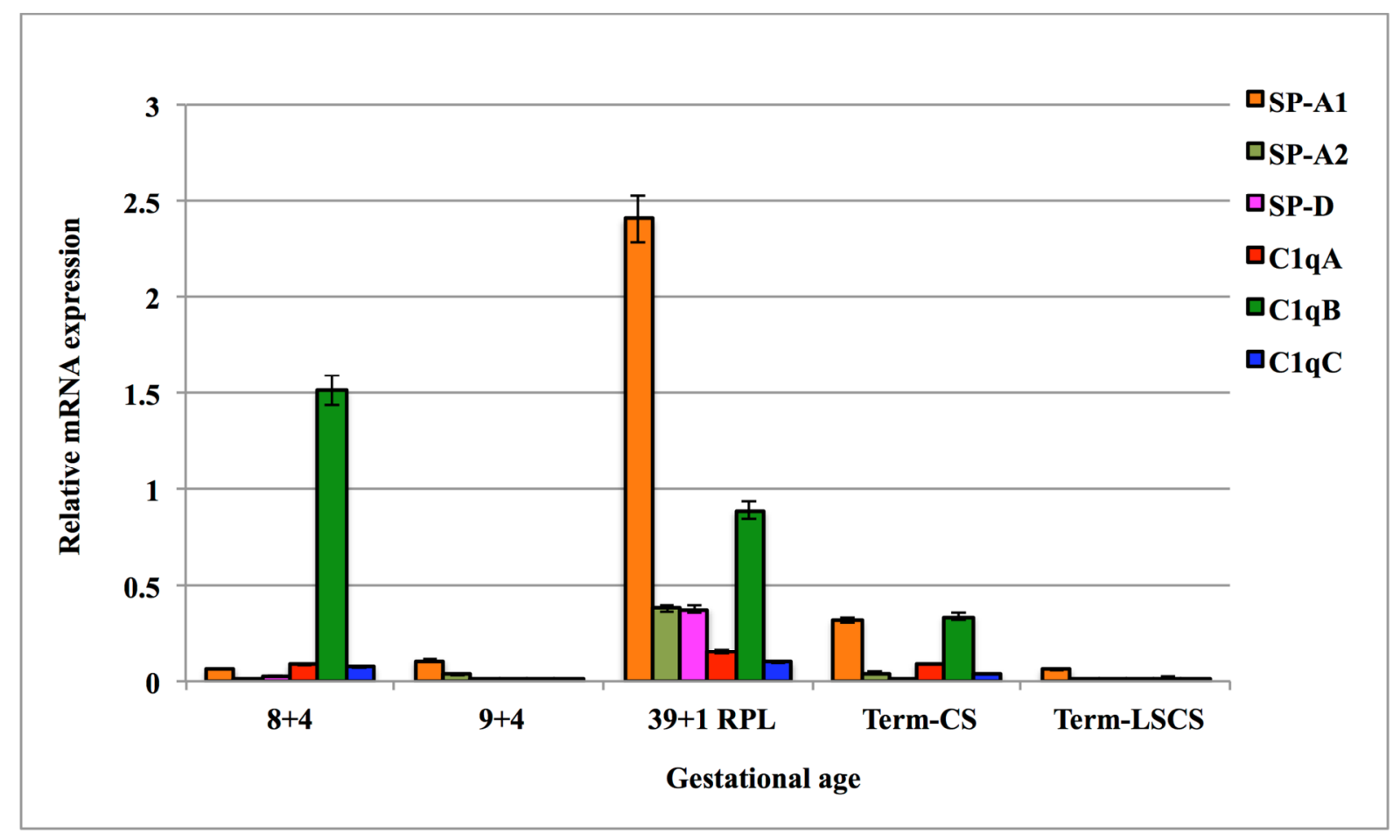

Figure 5B: Madhukaran et al 

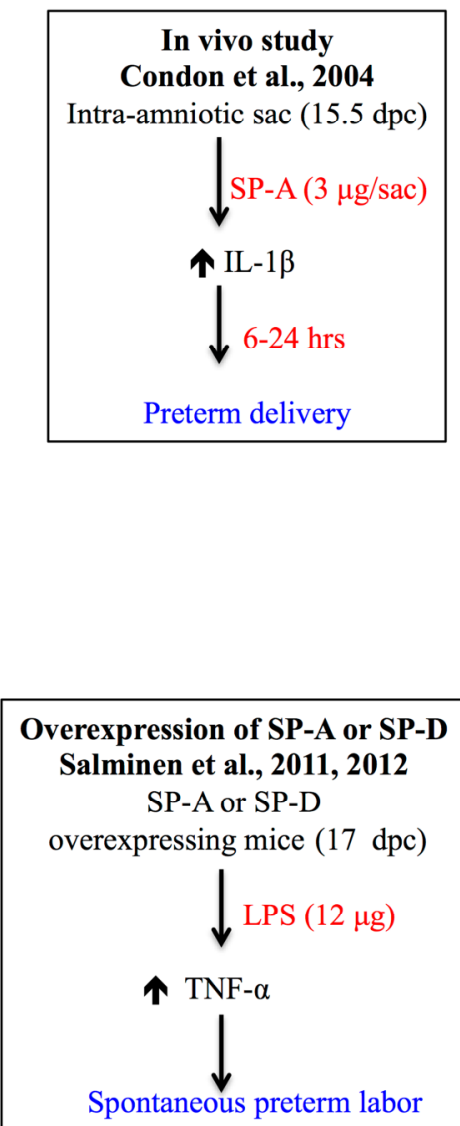

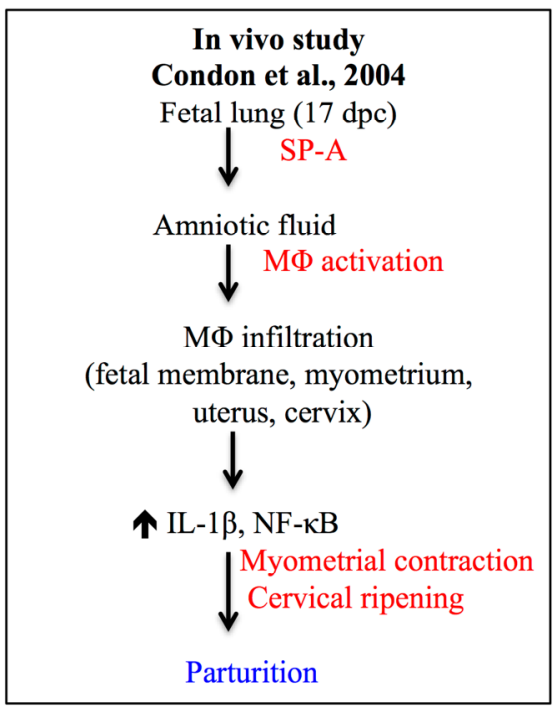

In vivo study

Condon et al., 2004

Amniotic fluid compartment

$\begin{gathered}\text { SP-A antibody } \\ (\text { SN50) }\end{gathered}$
IL-1 $\beta$
24 hrs
ed parturition

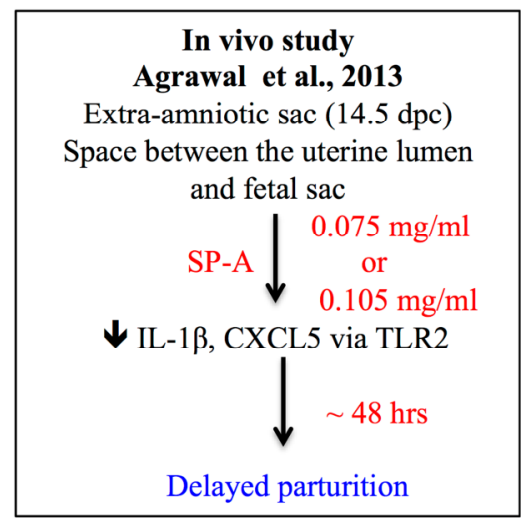

Knock out study

Montalbano et al., 2013

$\mathrm{SP}-\mathrm{A} / \mathrm{D}^{-/-}(18.5 \mathrm{dpc})$

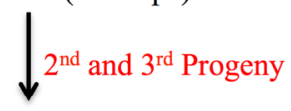

IL-1 $\beta$, IL-6, CX-43, OXTR

$\downarrow \sim 24 \mathrm{hrs}$

Delayed parturition

Figure 6: Madhukaran et al 


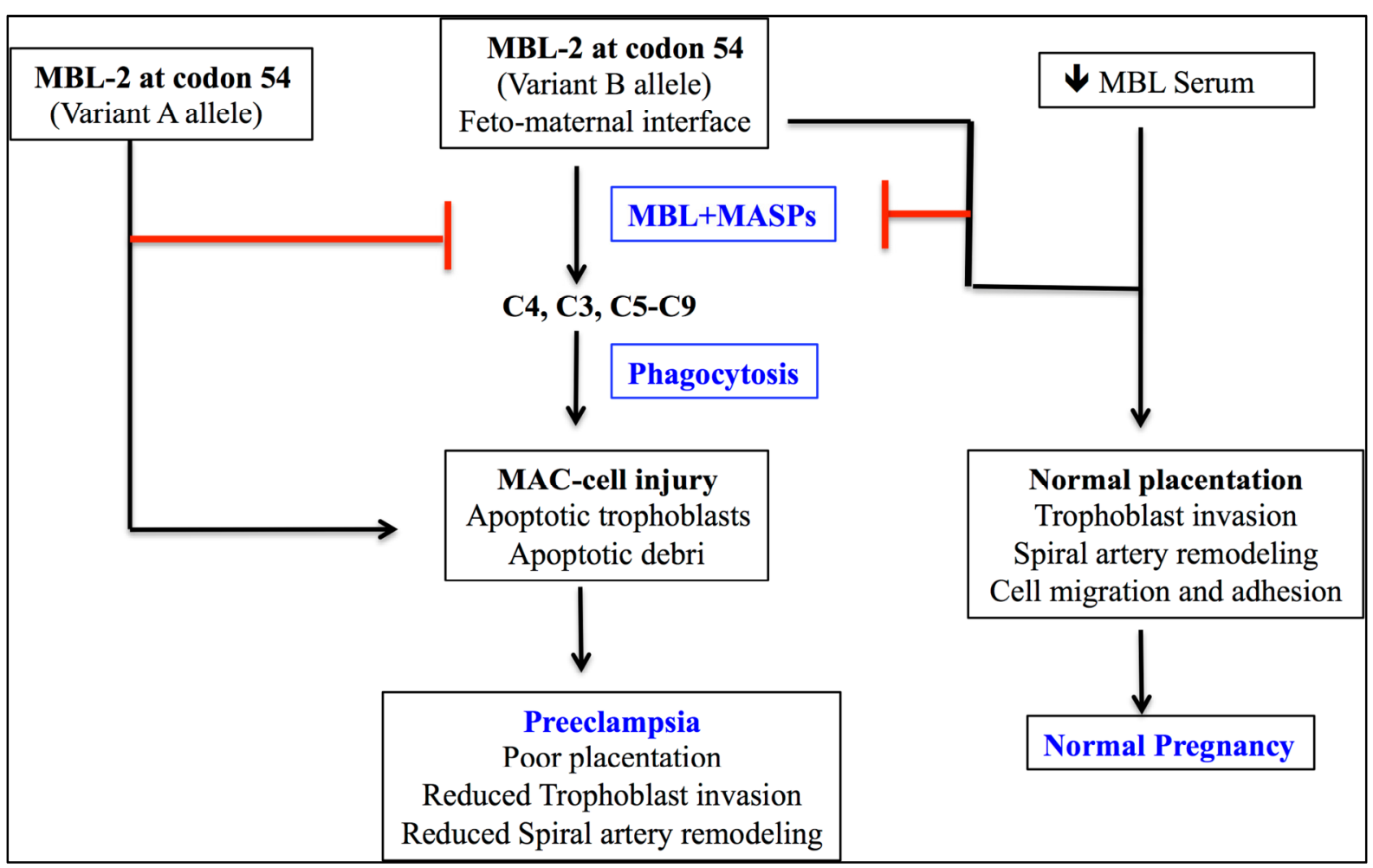

Figure 7: Madhukaran et al 